Economia e Sociedade, Campinas, Unicamp. IE. http://dx.doi.org/10.1590/1982-3533.2020v30n1art12

\title{
Sexual orientation in Brazil using unconditional quantile regression *
}

\author{
Daniel Suliano ** \\ Alexsandre Lira Cavalcante ${ }^{* * *}$ \\ Luciana Rodrigues ${ }^{* * * *}$
}

\begin{abstract}
This paper seeks to complement the underexplored dimension of sexual orientation-based differences in Brazilian incomes. Studies addressing the theme in Brazil have not recognized hitherto the main determinants of wage inequality along the wage curve, given that only data from the 2010 Brazilian Census conducted by the Institute of Geography and Statistics (IBGE) has been used up until now. Thus, importantly, this is the first paper using pooled data from the Continuous National Household Sample Survey (Continuous PNAD) of 2012 to 2016 to evaluate income differentials based on sexual orientation, employing the general Oxaca-Blinder (1973) decomposition method, which in turn is based on Recentered Influence Function (RIF) regressions proposed by Firpo, Fortin and Lemieux (2007). Findings: the composition effect presents favorable results for homosexuals as a group effect (both gays and lesbians), regarding demographic changes and human capital as well as activity and occupational sorting. On the other hand, there is no evidence of discriminatory effects on homosexuals in the context of the labor market. This is in sharp contrast with the effect of sexual orientation found in the existing literature.
\end{abstract}

Keywords: Sexual orientation, Continuous PNAD, Recentered influence function.

\section{Resumo}

\section{Orientação sexual no Brasil utilizando decomposição quantílica incondicional}

Este trabalho busca complementar a incipiente literatura do Brasil que discorre sobre os diferenciais de rendimentos a partir da orientação sexual. Até então, estudos dessa temática no país não fizeram uso de quais são os determinantes da desigualdade salarial ao longo da curva de salários, além de utilizarem apenas a base de dados do censo demográfico 2010 do Instituto Brasileiro de Geografia e Estatística (IBGE). Nesse trabalho utilizou-se, de forma pioneira, a Pesquisa Nacional por Amostra de Domicílios Contínua (PNAD Contínua) dos anos de 2012 a 2016 do IBGE, além de uma generalização do método de decomposição de Oaxaca (1973) e Blinder (1973) com base em regressões de Função de Influência Recentrada (FIR), proposta por Firpo, Fortin e Lemieux (2007). No efeito composição, os resultados se revelam favoráveis aos homossexuais, principalmente no grupo de demografia e capital humano e no grupamento de atividade e ocupação, tanto em gays como em lésbicas. Por outro lado, não foram encontradas evidências de efeitos discriminatórios em homossexuais no âmbito do mercado de trabalho, resultado que vai em direção contrária à literatura internacional especializada, utilizando outras formas de identificação da orientação sexual.

Palavras-chave: Orientação sexual, PNAD Contínua, Função de influência recentrada.

JEL J12, J20, J22.

* Article received on May 2, 2020 and approved on July 17, 2020. The authors are grateful for the CNPq support through the CNPq Universal Call/MCTI n. 01/2016 for Applied Humanities, Social and Social Sciences, Process n. 406564/2016-7.

${ }^{* *}$ Public Policy Analyst at the Institute of Research and Economic Strategy of Ceará (Ipece), Fortaleza, CE, Brazil. E-mail: daniel.suliano@ipece.ce.gov.br. ORCiD: https://orcid.org/0000-0002-6550-6139.

${ }^{* * *}$ Public Policy Analyst at the Institute of Research and Economic Strategy of Ceará (Ipece), Fortaleza, CE, Brazil. E-mail: alexsandre.lira@ipece.ce.gov.br. ORCiD: https://orcid.org/0000-0002-2212-7278.

${ }^{* * * * *}$ Technical Advisor at the Institute of Research and Economic Strategy of Ceará (Ipece), Fortaleza, CE, Brazil. E-mail: luciana.rodrigues@ipece.ce.gov.br. ORCiD: https://orcid.org/0000-0003-1811-405X. 


\section{Introduction}

Over the past decades, household surveys have been used as tool to more broadly reveal sexual preferences. All of the basic issues (i.e segregation and discrimination resources and their adequacy) of interest in the existing economic literature have been combined ${ }^{1}$. It should be noted, however, that part of this phenomenon is due to current antidiscrimination policies implemented by international organizations, such as the United Nations (UN), to protect lesbian, gay, bisexual and trans $(\text { LGBT) })^{2}$ citizens.

It is no coincidence that under the motto "equal rights, fair treatment", the Universal Declaration of Human Rights achieved to embed values in the rule of law in such a way that they consider observed experiences, values, and interests of all people, regardless of sex, gender and sexual orientation, or other prohibited grounds.

These institutional advances can be seen in several countries, independant of economic status. For example, as part of ending apartheid in South Africa, a new and clearly non-discriminatory constitution, namely the interim constitution was created in 1994 (Sagarra, 2015). At the same time, Olsen (2015) notes that since 1933, just before the Second World War, homosexual practice was no longer considered a crime in Denmark. It was the first country to recognize the union of same-sex couples, so that in Danish society the question of LGBT rights is not a pressing societal issue and is not used as a "political flag" open to immediate threats.

For legal purposes, the Supreme Federal Court (STF), in Brazil, declared same-sex marriage throughout the country as constitutional. The Court's decision has served as the touchstone for the National Council of Justice (CNJ) emphasizing, in 2013, through Resolution No. 175, the obligation of notaries to celebrate civil marriages between same-sex couples across the nation. Such decisions were crucial to overcoming the effects of long-held discrimination in society at large. It is now well established that sexual orientation is in no way reviewable under the equal protection clause ${ }^{3}$.

Running in line with such legal decisions, including recommendations from both the International Labour Organization (ILO) and the United Nations Statistical Commission (StatCom), the Brazilian Institute of Geography and Statistics (IBGE) reformulated methodologies according to its Integrated Household Survey System. The Continuous National Household Sample Survey (Continuous PNAD), as an integral core of the IBGE's Household Survey System (SIPD) based on a stringent mathematical background was designed to produce updated information in such a manner that conveys a more realistic picture concerning the country's economic capacities, presenting the

(1) In spite of increasing interest in sexual discrimination from scholars, Drydakis (2014) highlights that database limitations, due to the lack of effective socioeconomic information, have hindered studies in this subject area.

(2) Despite being a commom standard reference used in the UN documents as well as in Brazil, the acronym LGBT for lesbian, gay, bisexual and trans does not cover all spectrums of sexuality. Currently, the most complete one is LGBTTIS meaning lesbian, gay, bisexual, transvestite, transsexual, intersex and sympathizer, i.e, it affords a more accurate definition of sexual orientation based on selfidentification as opposed to biological sex. See Gorisch's (2014) for further details.

(3) For the sake of illustration, since the 2010 Brazilian Census, the term homosexual refers to the spouse of a person who is responsible for the household. 
key indicators that impact the workplace in the short, medium and long-term: income, housing, education, and permanent supplementary themes ${ }^{4}$.

Until recently, most studies on the topic of sexual orientation centered around wage differentials using nothing other than the 2010 Brazil Census (Details are provided in Corrêa; Irffi; Suliano, 2012; Casari; Monsueto; Duarte (2013); Suliano et al., 2016; Da Silva; dos Santos, 2016; Jacinto et al., 2017) ${ }^{5}$. This paper is the first to analyze the national reference sample drawn from the Continuous PNAD spanning a period of 5 years from 2012 to 2016. This paper employed a decomposition method (Oxaca-Blinder, 1973) by using Recentered Influence Function (RIF) Regressions as proposed by Firpo, Fortin and Lemieux (2007) together with reweighting techniques of DiNardo, Fortin and Lemieux (1996). A crucial result offered here is that positive income differentials tilt in favor of homosexuals (men and women). In turn, this result hinges on how one understands, regarding the distribution, the composition effects, which are squarely related to two groups, namely, demography and human capital, and activity and occupation.

The following section discusses the literature on sexual orientation. The second section provides a detailed outlook of the methodology to be used, the database as well as a step-by-step description of all the variables. This is followed by an analysis of the study's findings and the conclusion.

\section{Mapping out the literature based on sexual orientation}

Laregly speaking, every methodology has its limitations, alebit seldomly mentioned. For example, the General Social Survey $(\mathrm{GSS})^{6}$ or Census data fails to describe certain precise information on participants during the interview process. Another kind of methodology, namely 'experimental methodology', acknowledges the limitations of the former and considers the empirical stance to be valuable even when it is only able to provide less than conclusive, and therefore questionable, results.

In his seminal paper, Adam (1981) contributed substantially to the development of the latter (doing justice to its usefulness), rigorously enriching so-called 'correspondence testing'. His main purpose is to provide a finer (and real, since it is particularly difficult to document discrimination) outlook that explains discrimination during the hiring process $^{7}$ (selection and recruitment stage) in Ontario law firms by taking into consideration deep-rooted convictions that candidates have when identifying themselves within the workplace ${ }^{8}$.

Recent studies on the essential role of the relationship between sexual orientation and economic outcomes centered around experimental techniques include, among others, Drydakis (2009, 2011, 2015), Weichselbaumer (2003, 2015), Ahmed and Hammarstedt (2009), Ahmed, Andersson and Hammarstedt (2013b), Humpert (2016), Patacchini, Ragusa and Zenou (2015). Most of the

(4) For more details, see IBGE $(2014,2018,2019)$. Irffi (2019).

(5) For a recent development of this theme with particular emphasis on the 2013 National Health Survey (PNS), see Suliano and

(6) The first author to use GSS data to address the issue of discrimination was Badgett (1995).

(7) For further details, see Riach and Rich (2002).

(8) In particular, gay men (see Patacchini; Ragusa; Zenou, 2015). 
authors were strongly influenced by Badgett's (1995) illuminating account, i.e, pooled 1989-1991 data from the GSS plus the the Mincer equation (1974).

Data from the USA and Europe reveal the unquestionable result that gay men earn, on average, less than heterosexuals (see Klawitter; Flatt, 1998; Calandrino, 1999; Allegretto; Arthur, 2001; Clain; Leppel, 2001; Berg; Lien, 2002; Black et al., 2003; Blandford, 2003; Arabsheibani; Marin; Wadsworth, 2004; Tebaldi; Elmslies, 2006; Carpenter, 2007, 2008a). For example, the loss of earnings oscillates between $-2.4 \%$ (Allegretto; Arthur, 2001) to -34\% (Blandford, 2003) 9 .

It is not uncommon that minority groups, for example homosexuals (gay and lesbian people), experienced an overwhelming incidence of sexual prejudice in several areas of their lives, such as housing, healthcare, labour market, incuring particularly in earning differentials (Ahmed; Hammarstedt, 2009; Ahmed; Andersson; Hammarstedt, 2013a; Weichselbaumer, 2003; Patacchini; Ragusa; Zenou, 2015; Drydakis, 2011) ${ }^{10}$.

Another respected view has pointed out that wage differences relate, to some extent, to each family's interests (Becker, 1991). Indeed, it is true that same-sex couples dedicate their time and effort to household production and in the labor market differently compared to heterosexual couples.

Concerning the occupation itself, findings suggest that homosexual men have a higher estimated probability to be placed in female-oriented occupations and, thereby, are disfavored. On the other hand, lesbian women tend to be placed in male-oriented occupations, reaching high-level positions (due to their labour market investment, their higher likelihood of having no children), hence earn more compared with other women (Black et al., 2003; Blandford, 2003; Tebaldi, Elmslie, 2006) $)^{11}$.

Regarding discrimination, Ozturk (2011) discusses its main determinants within the context of the hiring process. Using the framework of the queer theory together with an analytical approach (snowball sampling), the author finds significant evidence that homosexuals are always at a disavantage in receiving offers, so do not mention their sexuality during the hiring process.

Despite being the target of jokes or comments about their stereotypical characterisations, lesbians tend to earn more (Clain; Leppel; 2001). This finding is also corroborated by Peplau and Fingerhut (2004). However, interestingly, the results provided by these authours show that leasbians avoid costly personal consequences by searching for non-traditional occupations, which are less competitive than other more traditional occupations.

In fact, there is evidence that highlights wage differences in the workplace in virtue merely of sexual orientation. For different reasons, according to Blandford (2003), Ueno, Roach and PeñaTalamantes (2013), lesbians and bisexuals have proved to be extraordinarily successful in receiving

(9) On the other hand, lesbians exhibit higher than average incomes as compared with their heterosexual counterparts (See Clain; Leppel, 2001; Berg; Lien, 2002; Black et al., 2003; Blandford, 2003; Arabsheibani; Marin; Wadsworth, 2004; Jepsen, 2007; Carpenter, 2008a; Plug; Berkhout, 2008; Ahmed; Andersson; Hammarstedt, 2013a; Humpert, 2016). This is in contrast with the Brazilian record. Using OLS estimators and data from the 2010 Brazilian Census, Suliano et al. (2016) found that gay couples earn aproximately $25 \%$ more. In addition, using Heckman's method, the authors found that lesbians earn $13 \%$ more.

(10) Drydakis (2011) carried out an experiment to estimate the probability for lesbian candidates receiving an invitation for an interview. Consequently, lesbians received $27.7 \%$ less offers than heterosexual women (in terms of wages, this represents a loss of $6.1 \%$ ).

(11) Dilmaghani (2017) predicted that the wage premium of lesbians is due to the large amount of overtime. 
offers of jobs that are largely male-identified and have higher incomes than other women. In contrast, gay and bisexual men are predominantly placed in female-identified allocations, i.e, in less demanding skilled jobs, thus dimishing their human capital returns.

As far as the labor supply is concerned, Tebaldi and Elmslies (2006) reveal that gay men work about $8 \%$ less hours weekly than their heterosexual counterparts. On the other hand, lesbians in a registered partnership receive more job offers than married women. Additionally, there is a positive effect on labor supply for heterosexual men who have dependents. The reverse can be held for gay men, reducing their labor supply by about $3 \%^{12}$.

Carpenter (2005) focused on wage differences for a large sample of bisexual (men and women) in California: they earn $10 \%$ less than heterosexual men and women. In Australia, for different reasons, including job loss and harassment, young lesbians earn 30\% less than heterosexual women (Carpenter, 2008b). Using such an identity model designed by Akerlof and Kranton (2000), Plug and Berkhout (2008) found weak evidence of discriminatory effects within the labor market. In fact, there was a slight difference in terms of lower pay (3\% to 4\%) for gays and bisexuals with graduate degrees in the Netherlands.

Centered around policies that prohibited any sort of discrimination based on sexual orientation, Klawitter and Flatt (1998) analyzed the effects on individual earnings and familiy income. Using data from the 1990 United States census, as for public and private jobs in a large collection of cities and counties, the authors succeeded in showing that thanks to job protection, same-sex couples enjoy, on average, direct increases in their earnings.

Laurent and Mihoubi (2012), using the Oaxaca-Blinder method, highlight the difficulties when estimating the effects of wage discrimination between gays and heterosexuals. Using the Oaxaca-Blinder method (1973), they observed the occurrence of wage discrimination ranging from $-6.3 \%$ within the private sector to $-5 \%$ in the public sector. Gay men exhibit low relevant educational skills comparaed to heterosexuals.

From another viewpoint, Antecol, Jong and Steinberger (2008) used the 2000 US Census data to show, utilizing the decomposition introduced by DiNardo, Fortin, Lemieux (1996), changes in the wage distribution. This type of approach makes it possible to analyze the differentials based on observable characteristics, by specifying the relative importance of human capital and occupation.

A major semiparametric study (in the manner of DiNardo, Fortin, Lemieux (1996)) to identify labor supply differences between heterosexual couples and lesbians was carried out by Antecol and Steinberger (2013). Using data from the 2000 American census, the study predicts, on average, that labor supply of heterosexual couples was affected by children, whose effect is not uniformly distributed regarding annual hours of work. In addition, there are incentives for both lesbian and heterosexual couples regarding the division of labor in domestic and other work-related activities thanks to the increasing returns on investment in human capital.

(12) Black, Sanders and Taylor (2007) argued that when bringing up children (including related expenditure), the lives of homosexual couples in terms of time and efforts drastically change. 


\section{Dataset and methodological strategy}

\subsection{Models}

In the present study, the Mincer equation (1974) is employed, and labor wage logarithm (1 hour worked) is considered the dependent variable, as follows:

$$
\ln \left(w_{i}\right)=\alpha+\varphi C S D+\beta x^{\prime}+\varepsilon_{i}
$$

$\ln \left(w_{i}\right)$ represent the resulting variable, $\alpha$ a term intercept, CSD consists of a dummy used for different-sex couples, $x_{i}^{\prime}$ is a vector that is observed in several attributes across groups (all of them provided in Picture 1), $\varepsilon$ is the error term as.$N \sim(0,1)$.

It follows that, under the assumption of differences in mean wages due to observed characteristics between the two groups in question (heterosexual/homosexuals), the Blinder-Oaxaca method (1973) is used in order to decompose these differences, namely:

$$
\Delta w_{C M S}-\Delta w_{C S D}=\left[E\left(X_{C M S}\right)-E\left(X_{C S D}\right)\right] \widehat{\beta_{C S D}}+E\left(X_{C S D}\right)\left[\widehat{\beta_{C M S}}-\widehat{\beta_{C S D}}\right]
$$

In that case, $C M S$ are same-sex couples. An interesting feature of the Oaxaca-Blinder method is that it estimates wage gaps: one decomposes differences in mean wages (between the two groups) into a wage structure effect and a composition effect, dividing them into the contribution of each covariate.

However, Firpo, Fortin and Lemieux (2007) consider that any adequate treatment of wage gaps is limited because the notion requires a sort of flexible analysis. The authors defend a solution which is based on the Oaxaca-Blinder method, but which goes beyond it, by making a plea for a distributional measure, regarding not only the mean but also different points of the distribution (for there is an ill-understood heterogeneous universe of characteristics). The slight modification is that the dependent variable is then replaced by the corresponding recentered influence function $(R I F)$ regressions.

Following Hampel et al. (2005), let $v=v(F)$ be a general function. An influence function is a kind of heuristic tool for which $v$ is determinated in the presence of outlier data whenever $F$ is replaced by empirical distribution as follows:

$$
F I(y, v(F))=\lim _{\varepsilon \rightarrow 0}\left\{\frac{v\left[(1-\varepsilon) \cdot F+\varepsilon \cdot \delta_{y}\right]-v(F)}{\varepsilon}\right\}, 0 \leq \varepsilon \leq 1
$$

Such that $F$ represents the distribution function of $Y$. Where $\delta_{y}$ is a distribution with added mass at the value $y$.

By adding $v(F)$ to $I F$, it turns out the $R I F$ is given as:

$F I R(y, v)=v(F)+F I(y, v)$

In the mean case, regarding $v(F)$ as the expectation, notice that $I F$ will be the residual evaluated at $y$ and $R I F$ will follow immediately from it.

$$
F I(y, \mu)=\lim _{\varepsilon \rightarrow 0}\left\{\frac{(1-\varepsilon) \cdot \mu+\varepsilon \cdot y-\mu}{\varepsilon}\right\}=y-\mu, e \operatorname{FIR}(y, \mu)=\mu+y-\mu=y
$$


Consequently, the coefficients yielded by means of RIF regressions will be tantamount to those of ordinary least squares regressions.

When the statistic of interest is a specific quantile $\tau$ evaluated at the distribution, then:

$$
F I\left(y, q_{\tau}\right)=\frac{\tau-I\left\{Y \leq q_{\tau}\right\}}{f_{y}\left(q_{\tau}\right)}
$$

Where $q_{\tau}$ means the $\tau^{\text {th }}$ unconditional quantile of $Y, f_{y}\left(q_{\tau}\right)$ estimates the density at the $\tau$ quantile $\left(q_{\tau}\right)$ and $I\left\{Y \leq q_{\tau}\right\}$ is a variable ranging over $Y$ up to the limit. By definition,

$$
\operatorname{FIR}\left(y, q_{\tau}\right)=q_{\tau}+\operatorname{FI}\left(y, q_{\tau}\right)
$$

When the conditional expectation of $\operatorname{RIF}\left(y, q_{\tau}\right)$ is modelled in function of the explanatory variables, $X, E\left[R I F\left(y, q_{\tau}\right) \mid X=x\right]=m_{\tau}(x)$, a $R I F$ regression is tantamount to Unconditional Quantile Regression (Firpo; Fortim; Lemieux, 2009). By $R I F$ definition, $E_{X} E\left[R I F\left(y, q_{\tau}\right) \mid X\right]=q_{\tau}$, therefore $E_{X}\left(\frac{d m_{\tau}(x)}{d X}\right)$ can be interpreted as a marginal effect of a small change concerning the distribution of covariates in the unconditional quantile $\tau$ of $Y$, with everything else remaining constant.

According to Firpo, Fortim and Lemieux (2007), procedures for estimating Unconditional Quantile Regressions are similar to those of OLS regression, namely, taking a specific $\tau$ quantile to estimate its $R I F$ as for $Y$ following (04) and (05). It turns out that $q_{\tau}$ is estimated using a sample estimate of unconditional $\tau ; f_{y}\left(q_{\tau}\right)$ at $q_{\tau}$ is estimated using the Kernel method. Finally, OLS is applied to $\operatorname{RIF}\left(y, q_{\tau}\right)$ on the observed covariates $X$.

An additional feature of Unconditional Quantile Regressions is that their results can be directly applied to the Oaxaca-Blinder method, by observing the factors that affect the wage income differentials based on sexual orientation throughout the whole distribution, as well as to the proposed decomposition method by Firpo, Fortim and Lemieux (2007). This represents changes in income distributions between the two groups attached to the statistics. Finally, the total differential is given by:

$$
\Delta^{v}=v\left(F_{y A}\right)-v\left(F_{y B}\right)
$$

where $v\left(F_{y r}\right)$ represents a statistic of wage distribution between the two groups $(r=A, B) ; A$ and $B$ are said to be $C S D, C M S$, respectively. In oder to analyze changes in the distribution of wages, the decomposition is divided up into two components: (i) distribution of observed characteristics of groups and (ii) distribution of wage structure between the two groups, which is viewed from the sexual orientation standpoint. To do this, it is necessary to build a counterfactual for simulating the distribution with respect the $C S D$ wage structure and the $C M S$ distribution of characteristics (observable and unobservable). Consequently:

$$
\begin{gathered}
\Delta^{v}=\left[v\left(F_{y B}\right)-v\left(F_{y C}\right)\right]+\left[v\left(F_{y C}\right)-v\left(F_{y A}\right)\right] \\
\Delta^{v}=\Delta_{S}^{v}+\Delta_{X}^{v}
\end{gathered}
$$

The first term represents the unexplained part of the decomposition - coefficient effect (return) related to labor market, which is, by definition, a measure of the difference between estimated coefficients of the covariates for each group. The second term is the quantity effect -i.e, the explained 
part of the decomposition - characteristic effect, which refers to the difference in the resource allocation for each group, where the difference in income between couples is explained by the fact that heterosexuals have more favorable characteristics.

Applying the expected value of the $R I F$, assuming that the specification is linear, the following equations for observed and counterfactual distributions are given, respectively:

$$
\begin{aligned}
& v\left(F_{y B}\right)=E\left[F I R\left(y_{r} ; v_{r}\right) \mid X, R=r\right]=X_{r} \beta_{r} \text { para } r=A, B \\
& v\left(F_{y C}\right)=E\left[F I R\left(y_{A} ; v_{C}\right) \mid X, R=B\right]=X_{C} \beta_{C}
\end{aligned}
$$

Following Barsky et al. (2002), Firpo, Fortin and Lemieux (2007) devised an equation for combining FIR regression with reweighting procedures (in the manner of DiNardo; Fortin; Lemieux, 1996). Such a reweighting factor is given as:

$$
\varphi(X)=\frac{\operatorname{Pr}[R=B \mid X]}{\operatorname{Pr}[R=A \mid X]} \cdot \frac{\operatorname{Pr}[R=A]}{\operatorname{Pr}[R=B]}
$$

$\operatorname{Pr}[R=r \mid X]$ represents the probability of belonging to group $r, X$ will denote individual characteristics, $\operatorname{Pr}[\mathrm{R}=\mathrm{r}]$ indicates the proportional measure of individuals belonging to $r$. This weighting factor can be estimated by using the predicted probabilities to calculate the value for each observation. This weighting factor can be estimated as for $\operatorname{Pr}[R=B \mid X]$ by using the predicted probabilities to calculate $\overline{\varphi(X)}$ for each observation.

$$
\left.\widehat{\beta_{r}}=\left(\sum_{i \in r} \widehat{w_{r}} \cdot X_{i} \cdot X^{\prime}{ }_{i}\right)^{-1} \cdot \sum_{i \in r} \widehat{w_{r}} \cdot F \operatorname{IR} \widehat{\left(y_{r l}\right.} ; v_{r}\right) \cdot X_{i}, \quad \text { as for } r A, \mathrm{~B}
$$

$\widehat{w_{r}}$ is the corresponding weighting factor to the composition of the total sample. Finally, the counterfactual is estimated as:

$$
\begin{aligned}
& \left.\widehat{\beta_{C}}=\left(\sum_{i \in A} \widehat{\varphi\left(X_{l}\right)} \cdot X_{i} \cdot X^{\prime}{ }_{i}\right)^{-1} \cdot \sum_{i \in A} \widehat{\varphi\left(X_{l}\right)} \cdot \operatorname{FIR} \overline{\left(y_{A l}\right.} ; v_{C}\right) \cdot X_{i} \\
& \overline{X_{C}}=\sum_{i \in A} \widehat{\varphi\left(X_{l}\right)} \cdot X_{i}
\end{aligned}
$$

It turns out that the decomposition is obtained as follows:

$$
\begin{aligned}
& \hat{\Delta}^{v}=\left[\overline{X_{B}} \hat{\beta}_{B}-\bar{X}_{C} \hat{\beta}_{C}\right]+\left[\bar{X}_{C} \hat{\beta}_{C}-\overline{X_{A}} \hat{\beta}_{A}\right] \\
& \hat{\Delta}^{v}=\hat{\Delta}_{S}^{v}+\hat{\Delta}_{X}^{v}
\end{aligned}
$$

In turn, the composition effect, $\hat{\Delta}_{S}^{v}$, can be divided up into two componentes, namely, the leading term $\left(\bar{X}_{C}-\bar{X}_{A}\right) \hat{\beta}_{A}$ which is added to the specification error $\bar{X}_{C}\left(\hat{\beta}_{C}-\hat{\beta}_{A}\right)$ such that:

$$
\hat{\Delta}_{X}^{v}=\left(\bar{X}_{C}-\bar{X}_{A}\right) \hat{\beta}_{A}+\bar{X}_{C}\left(\hat{\beta}_{C}-\hat{\beta}_{A}\right)
$$

The specification error tends to be zero unless linear specification of the model is certain, since $\operatorname{plim}\left(\hat{\beta}_{C}\right)=\operatorname{plim}\left(\hat{\beta}_{A}\right)$. As for the whole decomposition, in which each explanatory variable is estimated, the composition effect can be written as follows: 


$$
\hat{\Delta}_{X}^{v}=\sum_{k=1}^{K}\left(\bar{X}_{C k}-\bar{X}_{A k}\right) \hat{\beta}_{A}
$$

The structural wage effect is then defined by:

$$
\hat{\Delta}_{S}^{v}=\bar{X}_{B}\left(\hat{\beta}_{B}-\hat{\beta}_{C}\right)+\left(\bar{X}_{B}-\bar{X}_{C}\right) \hat{\beta}_{C}
$$

This effect is constrained by the first term since in large samples, with a correct estimation of the weighting factor, the weighting error tends to be zero. The unconditional quantile regression procedure provides a way to measure partial effects of the variable, by assuming that marginal changes in $X$ have no impact on the joint distribution of $X$ and $y$.

\subsection{Database and description of variables}

As previously mentioned, the present study uses pooled data from the Continuous National Household Sample Survey (Continuous PNAD) from 2012 to 2016. This is the exact period in which the national economy reaches the most promissing levels of employment, as economic activity reaches an optimal level in the second quarter of 2014. At the same time this period symbolizes the end of a sound economic expansion that lasted 20 quarters ${ }^{13}$. Within this context, dummies for the years 2012, 2013 and 2014 were added up in order to capture the temporal aspect under consideration.

As for the dependent variable, the relationship between the effective monthly income of all jobs by total hours worked multiplied by 4.5 was analyzed. In addition, incomes were deflated to 2019 constant prices using the Brazilian Consumer Price Index (IPCA) ${ }^{14}$.

Detailed in Picture 1 below, the variables of the study are classified into four groups:

(i) the first group contains variables that describe demographic characteristics and human capital, i.e. a dummy variable for those who self-declared as White/Asian considering reference categories (Black, Mixed-race, Indigenous); variables for years of schooling and age (measured both in years and squared years), as well as a variable that specifies the amount of people belonging to the family (according to La Croix and Doepke (2003), who indentified that families exhibiting less human capital are willing to have more children).

(ii) the second group represents the labor market, containing variables for tenure (also in its quadratic term); dummies for union membership, formal jobs and function level (occupation).

(iii) the third group presents variables that describe the main activity and occupations.

(iv) the fourth group contains variables for geographic locations, dummies for region and times. As for the geographic variable it is worth highlighting those who live in the Northeast, Southeast, South or Center-West of Brazil, urban and rural areas.

(13) See the official statement of August 2015 from the Economic Cycle Dating Committee (CODACE). Appeared in 2008, the main aim of the CODACE is to determine a chronology of Brazilian business cycles.

(14) Regarding the Continuous PNAD is a nation-wide survey, price and weighted (in particular to areas that lack a price index survey) índices were settled on according to IBGE (2018b) for all Federation Units (UF). 
Picture 1

Description of variables

\begin{tabular}{|c|c|}
\hline Variables & Description \\
\hline \multicolumn{2}{|r|}{ Dependent Variable } \\
\hline $\begin{array}{l}\text { Monthly gross } \\
\text { income }\end{array}$ & $\begin{array}{l}\text { effective monthly income related to all jobs for people aged } 14 \text { or over (only for people who } \\
\text { received cash, products or merchandise in any job) }\end{array}$ \\
\hline \multicolumn{2}{|r|}{ Explanatory variables } \\
\hline \multicolumn{2}{|r|}{ Demographic characteristics and human capital } \\
\hline White/Asian & if the person calls themselves Asian or white \\
\hline Family size & the number of people in a household \\
\hline Education & average years of schooling \\
\hline Age & age measured in years (a proxy for experience) \\
\hline$A g e^{2}$ & age measured in squared years (positive nonlinear effect but decreasing rates) \\
\hline \multicolumn{2}{|r|}{ Labor Market } \\
\hline Tenure & number of hours at work until the last day of the reference week \\
\hline Tenure ${ }^{2}$ & number of hours (in squared) at work until the last day of the reference week \\
\hline Labor union & if the person is a member of a labor union \\
\hline Formal work & $\begin{array}{l}\text { as for the reference week, it is said to be "formal": all government workers, domestic workers } \\
\text { with a formal contract, self-employed with CNPJ registration. }\end{array}$ \\
\hline Occupation & position occupied during the reference week for persons aged 14 or over ${ }^{\text {(a) }}$ \\
\hline \multicolumn{2}{|r|}{ Groups of Occupations and Activities } \\
\hline $\begin{array}{l}\text { Group of main } \\
\text { activity }\end{array}$ & group of main activity (primary job) during the reference week for persons aged 14 or over ${ }^{\text {(b) }}$ \\
\hline $\begin{array}{l}\text { Group of } \\
\text { occupations }\end{array}$ & $\begin{array}{l}\text { group of occupations with regard the main activity during the reference week for persons aged } \\
14 \text { or over (c) }\end{array}$ \\
\hline \multicolumn{2}{|r|}{ Geography and Time } \\
\hline Metropolitan area & resident in the metropolitan area \\
\hline Census area & resident in the urban area \\
\hline Southeast & resident in the southeast region \\
\hline South & resident in the south region \\
\hline Center-west & resident in the center-west \\
\hline 2012 year & dummy for 2012 year \\
\hline 2013 year & dummy for 2013 year \\
\hline 2014 year & dummy for 2014 year \\
\hline
\end{tabular}

Source: Elaborated by the authors from the Continuous PNAD.

(a) Added up dummies for employed persons (private and public sector); employers those different from the base reference such as housekeepers, self-employed and auxiliary family workers.

(b) Added up dummies for industry trade, maintenance and repair workers (general); accommodation and food; information, communication and financial, real estate, professional and administrative activities; public administration, defense and health insurance; education, human health and social services; other services. The reference base is constitued of agriculture, livestock, forest production, fishing and aquaculture; domestic services; undefined activities.

(c) Added up dummies for directors and managers; science and intellectual occupations; technicians and professionals; administrative support workers; service workers, shopkeepers and markets; skilled workers, construction workers and artisans, mechanical arts and other qualifications; basic occupations. The reference base is constitued of skilled workers in agriculture, forestry, hunting and fishing; plant and machine operators and assemblers; members of Brazilian armed forces, police and military firefighters; undefined occupations.

\section{Results and discussions}

\subsection{Descriptive statistics}

Table 1 presents the descriptive data as for sexual orientation (heterosexual couples of both gender, and homosexual couples of both gender). Regarding men, the comparison is made between 
gays vis-à-vis couples where the man is responsible for the household; for women, the lesbian couple is compared with their heterosexual counterpart, but the woman is now responsible for the household.

Regarding mean real income, higher values are found for both gays and lesbians, compared to their heterosexual counterparts. Considering the heterosexual men, their income is about $50 \%$ superior to that of gay men. As for lesbians, their mean real income is superior to that of heterosexual women, but they work 3.5 hours more compared with their heterosexual counterparts. Figure 1 presents the estimated density based on the natural logarithm of couples' total number of hours worked. It reveals that homosexual couples are favored, compared with their heterosexual counterparts.

Figure 1

Estimated density (natural logarithm of factual and effective incomes)
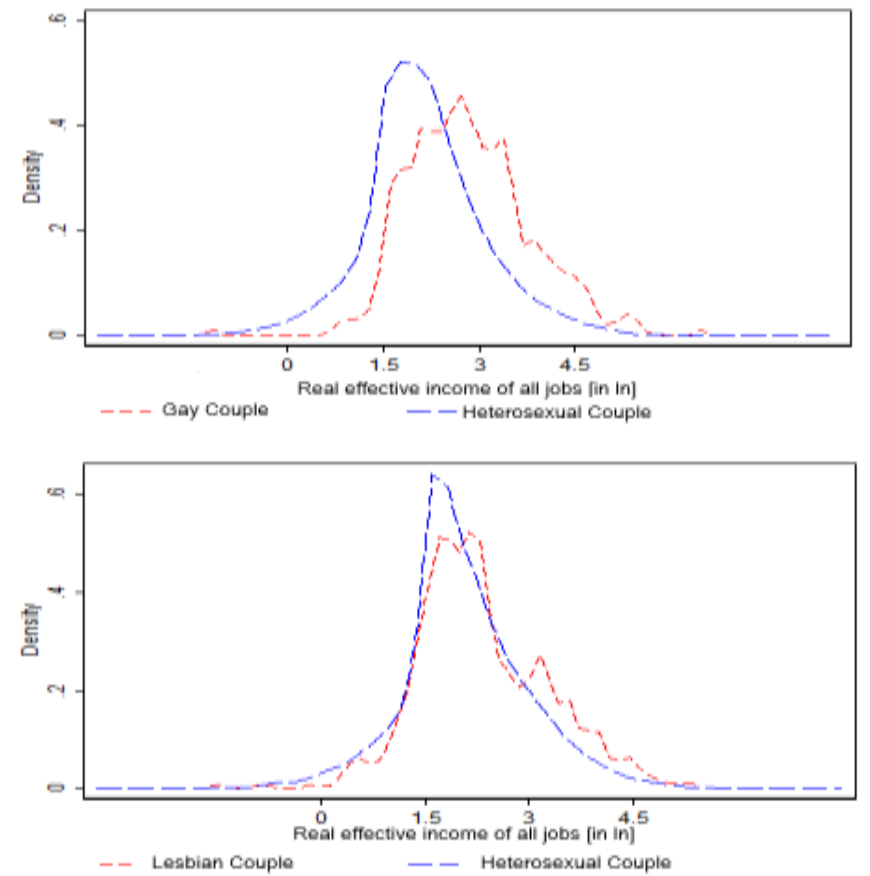

Source: Elaborated by the authors based on the Continuous PNAD.

As for characteristics associated with demography and human capital, Table 1 shows that it is clearly and uncontroversially true that gay men and lesbians are more educated: their mean years of schooling is above that of heterosexuals $(13.1 \%$ compared to $7.6 \%)$, but the reverse is true in a slightly different form for lesbians, compared with their heterosexual counterparts $(11.4 \%$ compared to $7.6 \%$ ). Homosexuals are also predominantly white/Asian, with their families, on average, being smaller than those of their heterosexual counterparts.

As for the characteristics associated with the labor market, homosexuals occupy higher ranks (78\%) than their heterosexual counterparts. They are predominantly public sector employees.

Regarding the third group, particular differences with respect allocation can be observed. For example, while gays work in areas such as communication and finance and education, heterosexual men can be found in industry and commerce. As for women, they are evenly distributed (both 
heterosexuals and lesbians make the majority of workers in commerce). As for occupational groups, gay men tend to work in areas such as science and business, while heterosexuals are skilled workers. Women (lesbian or heterosexual) work in services.

Finally, as far as area of residence is concerned, most minorities live in the southeast region of the country, as well as residential and metropolitan areas.

Table 1

Descriptive statistics

\begin{tabular}{|c|c|c|c|c|c|}
\hline \multirow{2}{*}{\multicolumn{2}{|c|}{ List of variables }} & \multicolumn{2}{|c|}{ Men } & \multicolumn{2}{|c|}{ Women } \\
\hline & & \multirow{2}{*}{\begin{tabular}{c|}
$\begin{array}{c}\text { Heterosexual } \\
\text { couples }\end{array}$ \\
$2,462.11$
\end{tabular}} & \multirow{2}{*}{\begin{tabular}{|c|} 
Gay couples \\
$4,780.76$ \\
\end{tabular}} & \multirow{2}{*}{$\begin{array}{c}\begin{array}{c}\text { Heterosexual } \\
\text { couples }\end{array} \\
1,915.95\end{array}$} & \multirow{2}{*}{$\begin{array}{r}\begin{array}{r}\text { Lesbian } \\
\text { couples }\end{array} \\
2,683.26\end{array}$} \\
\hline Dependent & Effective monthly income & & & & \\
\hline variables & Effective hours worked & 41.69 & 41.10 & 35.21 & 38.70 \\
\hline \multirow{4}{*}{$\begin{array}{l}\text { Demographic } \\
\text { Characteristics } \\
\text { and human } \\
\text { capital }\end{array}$} & Average years of schooling & 7.65 & 13.01 & 8.84 & 11.42 \\
\hline & White/Asian & 0.43 & 0.52 & 0.39 & 0.46 \\
\hline & Family size & 3.56 & 2.21 & 3.66 & 2.85 \\
\hline & Age & 47.13 & 37.84 & 43.21 & 36.93 \\
\hline \multirow{6}{*}{ Labor market } & Tenure & 3.60 & 3.62 & 3.50 & 3.33 \\
\hline & Formal & 0.54 & 0.78 & 0.59 & 0.64 \\
\hline & Labor union & 0.20 & 0.23 & 0.15 & 0.18 \\
\hline & A private-sector employee & 0.45 & 0.40 & 0.32 & 0.44 \\
\hline & A public-sector employee & 0.10 & 0.26 & 0.21 & 0.19 \\
\hline & Employer & 0.06 & 0.08 & 0.04 & 0.04 \\
\hline \multirow{14}{*}{$\begin{array}{l}\text { Groups of } \\
\text { primary } \\
\text { activities and } \\
\text { occupations }\end{array}$} & Industry & 0.13 & 0.08 & 0.10 & 0.08 \\
\hline & $\begin{array}{l}\text { Commerce, motor vehicles and } \\
\text { motorcycles repairing }\end{array}$ & 0.16 & 0.09 & 0.19 & 0.19 \\
\hline & Accommodation and food & 0.03 & 0.05 & 0.07 & 0.11 \\
\hline & $\begin{array}{l}\text { Communication and finance, real } \\
\text { estate, professional and administrative } \\
\text { activities }\end{array}$ & 0.08 & 0.20 & 0.08 & 0.13 \\
\hline & $\begin{array}{l}\text { Public administration, defense and } \\
\text { health insurance }\end{array}$ & 0.07 & 0.09 & 0.08 & 0.11 \\
\hline & $\begin{array}{l}\text { Education, social services and human } \\
\text { health }\end{array}$ & 0.04 & 0.21 & 0.19 & 0.16 \\
\hline & Other services & 0.02 & 0.20 & 0.06 & 0.05 \\
\hline & Directors and managers & 0.06 & 0.11 & 0.05 & 0.07 \\
\hline & Science and intellectual occupations & 0.05 & 0.28 & 0.14 & 0.18 \\
\hline & Mid-level technicians and professionals & 0.07 & 0.13 & 0.07 & 0.11 \\
\hline & Administrative support workers & 0.03 & 0.08 & 0.08 & 0.10 \\
\hline & $\begin{array}{l}\text { Service workers, shopkeepers and } \\
\text { markets }\end{array}$ & 0.13 & 0.24 & 0.27 & 0.27 \\
\hline & $\begin{array}{l}\text { Skilled workers, artisans, mechanical } \\
\text { arts and other qualifications }\end{array}$ & 0.19 & 0.06 & 0.05 & 0.07 \\
\hline & Basic occupations & 0.17 & 0.05 & 0.26 & 0.14 \\
\hline
\end{tabular}


Table 1 - Continuation

\begin{tabular}{c|l|c|c|c|c}
\hline \multirow{5}{*}{$\begin{array}{c}\text { Geography } \\
\text { and Time }\end{array}$} & Southeast & 0.27 & 0.39 & 0.23 & 0.32 \\
\cline { 2 - 6 } & South & 0.19 & 0.20 & 0.18 & 0.15 \\
\cline { 2 - 6 } & Center-west & 0.10 & 0.09 & 0.10 & 0.09 \\
\cline { 2 - 6 } & Urbain area & 0.67 & 0.93 & 0.81 & 0.94 \\
\cline { 2 - 6 } & Resident in the metropolitan area & 0.27 & 0.60 & 0.37 & 0.54 \\
\cline { 2 - 6 } & 2012 & 0.20 & 0.12 & 0.17 & 0.12 \\
\cline { 2 - 6 } & 2013 & 0.20 & 0.16 & 0.18 & 0.15 \\
\cline { 2 - 6 } & 2014 & 0.21 & 0.19 & 0.19 & 0.19 \\
\hline
\end{tabular}

Source: Elaborated by the authors based on the Continuous PNAD.

\subsection{RIF regressions}

Tables A.1.1 and A.1.2 (see Appendix 1) present the estimates of the unconditional quantile regressions for men (gay and heterosexual) and women (lesbian and heterosexual) by looking at the effects linked to covariates along the distribution of wages at different quantiles (0.1, 0.5 and 0.9$)$; the OLS estimate is also provided.

Regressions for homosexuals (gays and lesbians), either in the quantiles or even in the OLS estimates, presented a constrained set of explanatory variables that were statistically significant. As for heterosexuals (men or women), this does not occur.

However, when the results are statistically significant, the effects are no longer constant throughout the distribution, for both homosexuals or heterosexuals (both men and women), legitimating in this respect the use of quantile regressions. In fact, taking the age of men, and looking at the median and the 0.9 quantile, a positive and significant effect for both gays and heterosexuals can be observed. In turn, looking at the years of schooling for gays, the effects are non-significant in all quantiles, but positive and significant for heterosexuals.

For women, by analyzing the median and the 0.9 quantile, there is a positive and significant effect on the years of schooling for both lesbians and heterosexuals. On the other hand, for both race and age of lesbians, no statistical significance was observed in any of the quantiles analyzed. As for heterosexuals, these variables had a positive and significant effect in all quantiles analyzed $(0.1 ; 0.5$ and 0.9).

\subsection{Decomposing differentials}

RIF regressions for men and women are shown in tables A.2.1 and A.2.2 (see Appendix 2). The results make it possible to identify the wage differentials of homosexuals and heterosexuals given the resulting effects associated with characteristics and structural effects along the distribution. Figure 2 presents these same results.

The wage differentials based on sexual orientation are favorable to homosexuals (both men and women). These differentials are due to the composition effect (characteristic) over almost the entire distribution (only in 0.8 and 0.9 for women, and only in the last decile the results of this effect were not significant). In contrast, the results shown in tables A.2.1 and A.2.2 reveal that coefficients 
associated with the structural effect are insignificant in all the decompositions for men and significant only in the q80 for women. In this case, the effect of non-measurable characteristics is a reduction in the differences between them.

Figure 2 reveals that the total differential for men is slightly increases from decile q20 to q70, after which it begins to decrease. Taking the case of women, this differential also gradually increases from q20 to the median, decreasing in the subsequent decile and reaching a maximum in the q80 decile.

Considering men, the biggest differential occurs in the $30^{\circ}$ and $40^{\circ}$ deciles. In these two cases, if heterosexuals had the same characteristics as those of homosexuals, their remuneration would be $141 \%$ and $143 \%$ higher, respectively. The q10 decile was the lowest differential, accounting for 55\%. Taking women, the biggest differences occur in the $70^{\circ}, 30^{\circ}, 60^{\circ}$ and $40^{\circ}$ deciles. Given the $70^{\text {th }}$ decile, if heterosexual women had the same characteristics as those of lesbians, their remuneration would be $93 \%$ higher.

Figure 2

Homo/Heterosexual couples income decomposition

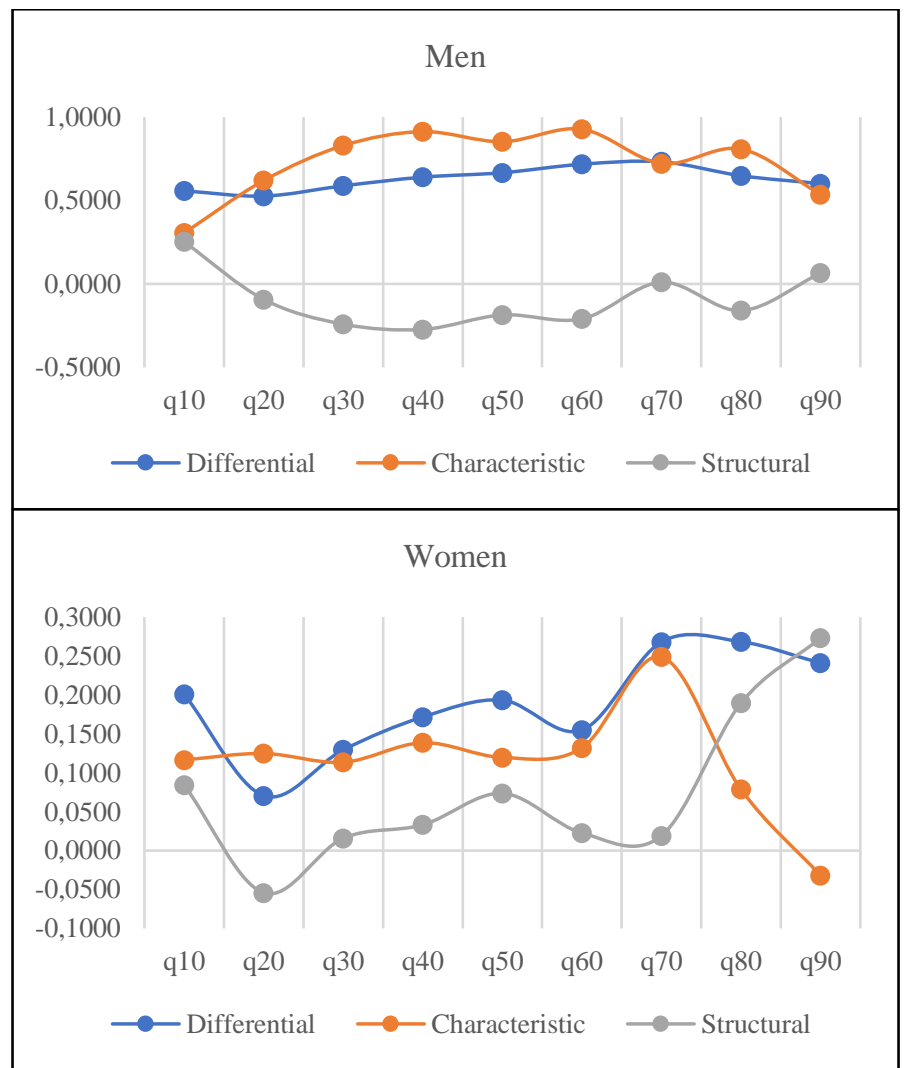

Source: Elaborated by the authors from the Continuous PNAD.

Tables A.2.3 and A.2.4 report the decomposition associated with between-group effects and within-group effects. Tables A.2.5 and A.2.6 present the decomposition relating the structural effect 
for men and women. As for the composition effect there is no statistical significance in all deciles for men or women. Regarding the coefficient effect, however, this behavior occurs in almost all decisions in all groups.

Regarding the composition effect, Figure 3 presents the decomposition as for the four groups in light of the composition effect, singling out demography and human capital and activity and occupation for men and women. For men, factors related to demography and human capital are of greater importance in the $80^{\circ}$ decile, the $40^{\circ}$ decile being the most prominent regarding activity and occupation. For women, in the $70^{\circ}$ decile, both groups present greater weight.

Figure 3

Characteristic effect on homo/heterosexual couples

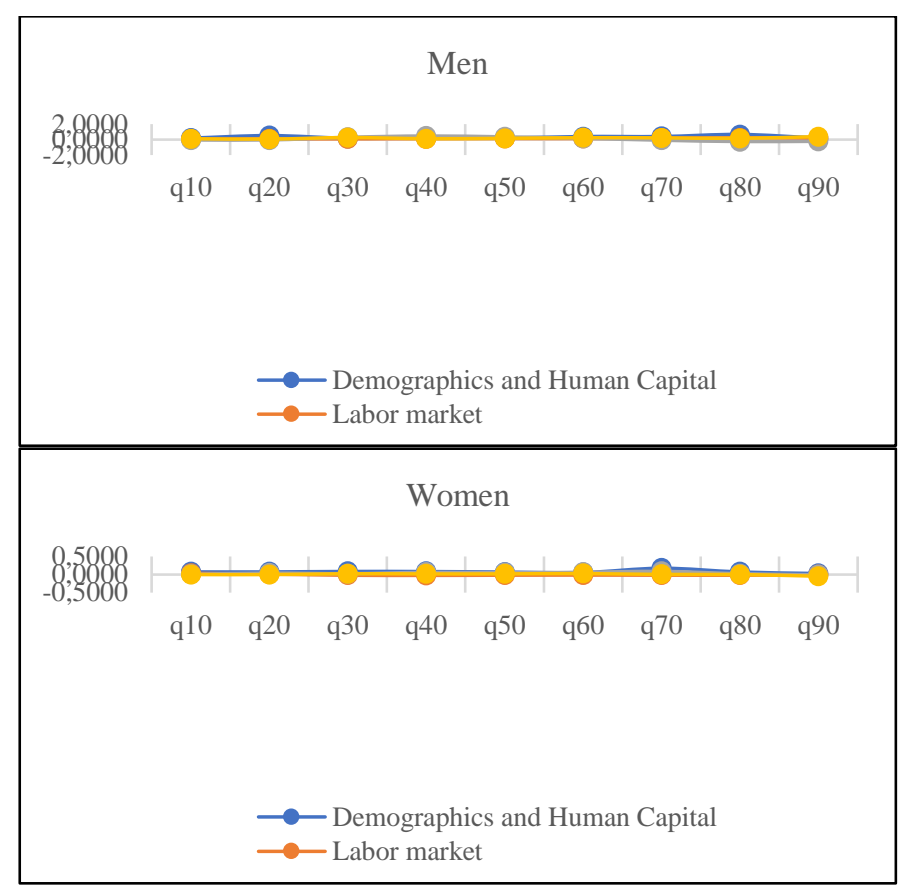

Source: Elaborated by the authors based on the Continuous PNAD.

Table A.2.3 highlights that the higher the decile from q60 to q80, the greater the importance attached to demographic and human capital, although it is in q20 where it shows the greatest weight (in the others it was not statistically significant). Indeed, demography and human capital explain about $84 \%, 43 \%, 55 \%$ and $82 \%$ for men in the $20^{\circ}, 60^{\circ}, 70^{\circ}$ and $80^{\circ}$ deciles, respectively. The characteristics of the activity and occupational group explain about $51 \%$ and $41 \%$ in the $40^{\circ}$ and $50^{\circ}$ deciles, respectively (in the others there is no statistical significance).

In turn, regrading the groups of women from the data in Table A.2.4, demographic and human capital characteristics explain about $76 \%, 61 \%, 58 \%$ and $70 \%$ in the $20^{\circ}, 30^{\circ}, 40^{\circ}$ and $70^{\circ}$ deciles, respectively (the others were not significant). The characteristics associated with activity and occupation in the $20^{\circ}, 40^{\circ}, 50^{\circ}, 60^{\circ}$ and $70^{\circ}$ deciles are explained in about $32 \%, 43 \%, 42 \%, 48 \%$ and $35 \%$, respectively. 
Finally, as already mentioned, the results associated with the decomposition attached to the structural effect are not significant, although in some deciles attached to certain groups there is significance at high percentages. For men, it is worth highlighting that the results became negative regarding occupation and activity in the $70^{\circ}$ and $90^{\circ}$ deciles. If gays had the same average return, even with different characteristics, $4.745 \%$ and $1.615 \%$, respectively, the wage difference would be due to the unobserved characteristics. For women, such a result stands out in the $40^{\circ}$ and $70^{\circ}$ deciles, but showing a positive sign, and this contributes to increasing the differential by about $4.745 \%$ and $1.615 \%$, respectively.

\section{Concluding remarks}

The aim of this paper was to complement the existing literature in Brazil that exploits the well-founded relationship between wage gaps and sexual orientation. While earlier studies are mainly based on the 2010 Brazilian Census data, the present paper uses, for the first time, pooled data from the Continuous PNAD from 2012 to 2016, a large nationally representative dataset containing a set of characteristics associated with demography, geography, labor market and human capital. In addition, the Oaxaca-Blinder (1973) method was used and extended by way of a give-and-take combination of RIF-regressions proposed by Firpo, Fortin and Lemieux (2007) and corresponding reweighting adjustment provided by DiNardo, Fortin and Lemieux (1996).

Concerning the results, RIF-regressions made it possible to observe differentials in favor of homosexuals (both men and women) due the composition effects (characteristics) at different points over the distribution. In turn, the effect related to coefficients (structural) was insignificant in all deciles related to men, but only significant for women in the $80^{\circ}$.

Given the corresponding composition effect for men, the differentials appear in almost all deciles over the distribution, being insignificant at the top and smaller at the bottom. The case is similar for women (with the exception of the smallest, which appears at the top of the distribution). The variables corresponding to demographic characteristics and human capital (race, family size, education, age, occupation) are emphasized. For men, they appear particularly at the top $\left(70^{\circ}\right.$ decile).

By means of these results, it follows that wage differentials in favor of homosexuals (gays and lesbians) are linked to personal characteristics, allocation of resources and human capital investment. Most studies have pointed out wage advantages as for homosexual couples, e.g, they are more likely to invest in human capital accumulation. In particular, as Becker (1991) highlighted, same-sex couples make choices with respect to intra-household allocation of tasks and their labour market skills from a different angle. These results are controversial.

Further, one must acknowledge as uncontroversial the statement that gays are at a disavantage in the workplace. One relevant step in an opposite direction was taken by the present paper. However, this result does not provide closure to the matter. In fact, one must take into account the underestimation (due to social norms) concerning the database analyzed here.

\section{References}

ADAM, B. D. Stigma and employ ability: discrimination by sex and sexual orientation in the ontario legal profession. Canadian Review of Sociology, v. 18, n. 2, p. 216-221, 1981. 
AKERLOF, G. A.; KRANTON, R. E. Economics and identity. Quarterly Journal of Economics, v. 115 , n. 3, p.715-753, Aug. 2000.

ALLEGRETTO, S. A.; ARTHUR, M. M. An empirical analysis of homosexual/heterosexual male earnings differentials: unmarried and unequal? Industrial \& Labor Relations Review, v. 54, n. 3, p. 631-646, 2001.

AHMED, A. M.; HAMMARSTEDT, M. Sexual orientation and earnings: a register data based approach to identify homosexual. Journal of Population Economics, v. 23, n. 3, p. 835-849, 2009.

AHMED, A. M.; ANDERSSON, L.; HAMMARSTEDT, M. Sexual orientation and full-time monthly earnings, by public and private sector: evidence from swedish register data. Review of Economics of the Household, v. 11, n. 1, p. 83-108, $2013 \mathrm{a}$.

AHMED, A. M.; ANDERSSON, L.; HAMMARSTEDT, M. Are gay men and lesbians discriminated against in the hiring process? Southern Economic Journal, v. 79, n. 3, p. 565-585, 2013 b.

ANTECOL, H.; STEINBERGER, M. D. Labor supply differences between married heterosexual women and partnered lesbians: a semi-parametric decomposition approach. Economic Inquiry, v. 51, n. 1, p. 783-805, 2013.

ANTECOL, H.; JONG, A.; STEINBERGER, M. D. The sexual orientation wage gap: the role of occupational sorting and human capital. Industrial \& Labor Relations Review, v. 61, n. 4, p. 518-526, 2008.

ARABSHEIBANI, G. R.; MARIN, A.; WADSWORTH, J. In the pink: homosexual heterosexual wage differentials in the UK. International Journal of Manpower, v. 25, n. 3/4, p. 343-354, 2004.

BADGETT, M. V. L. The wage effects of sexual orientation discrimination. Industrial \&Labor Relations Review, v. 48, n. 4, p. 726-739, 1995.

BARSKY, R.; BOUND, J.; CHARLES, K. K.; LUPTON, J. P. Accounting for the black-white wealth gap: a nonparametric approach. Journal of the American Statistical Association, v. 97, n. 459, p.663673, 2002.

BECKER, G. S. A treatise on the family. Harvard University Press, 1991.

BERG, N.; LIEN, D. Measuring the effect of sexual orientation on income: evidence of discrimination? Contemporary Economic Policy, v. 20, n. 4, p. 394-414, 2002.

BLACK, D.; MAKAR, R.; SANDERS, S.; TAYLOR, L. The earnings effects of sexual orientation. Industrial \& Labor Relations Review, v. 56, n. 3, p. 449-469, 2003.

BLACK, D.; SANDERS, S.; TAYLOR, J. The economics of lesbian and gays families. Journal of Economic Perspectives, v. 21, n. 2, p. 53-70, 2007.

BLANDFORD, J. M. The nexus of sexual orientation and gender in the determination of earnings. Industrial \& Labor Relations Review, v. 56, n. 4, p. 622-642, 2003.

BLINDER, A. S. Wage discrimination: reduced form and structural estimates. The Journal of Human Resources, v. 8, n. 4, p. 436-455, 1973. 
Daniel Suliano, Alexsandre Lira Cavalcante, Luciana Rodrigues

CARPENTER, C. S. Self-reported sexual orientation and earnings: evidence from California. Industrial \& Labor Relations Review, v. 58, n. 2, p. 258-273, 2005.

CARPENTER, C. S. Revisiting the income penalty for behaviourally gay men: evidence from NHANES III. Labor Economics, v. 14, p. 25-34, 2007.

CARPENTER, C. S. Sexual orientation, work, and income in Canada. Canadian Journal of Economics, v. 41, n. 4, p. 1239-1261, 2008a.

CARPENTER, C. S. Sexual orientation, income, and non-pecuniary economic outcomes: new evidence from young lesbians in Australia. Review of Economics of the Household, v. 6, n. 4, p. 391408, 2008b.

CALANDRINO, M. Sexual orientation discrimination on the UK labor market. University of Oxford, 1999. (Working Paper St. Antony's College).

CASARI, P.; MONSUETO, S.; DUARTE, P. Impacto da orientação sexual sobre o rendimento do trabalho. In: ENCONTRO NACIONAL DE ECONOMIA, 41, Foz do Iguaçu, 2013. Anais...

CLAIN, S. H.; LEPPEL, K. An investigation into sexual orientation discrimination as an explanation for wage differences. Applied Economics, v. 33, n. 1, p. 37-47, 2001.

COMITÊ DE DATAÇÃO DE CICLOS ECONÔMICOS (CODACE), 4 ago. 2015.

CORRÊA, M. V.; IRFFI, G.; SULIANO, D. Existe diferencial entre casais heterossexuais e homossexuais? Uma abordagem para o mercado de trabalho brasileiro. In: ENCONTRO NACIONAL DE ECONOMIA, 40, Porto de Galinhas, 2012. Anais...

DA SILVA, W. R.; DOS SANTOS, D. D. Trabalho e bem-estar: uma comparação entre casais heterossexuais e homoafetivos brasileiros. In: ENCONTRO NACIONAL DE ECONOMIA, 43, Foz do Iguaçu, 2016. Anais...

DE LA CROIX, D.; DOEPKE, M. Inequality and growth: why differential fertility matters. American Economic Review, v. 73, n. 4, p. 1093-1113, 2003.

DILMAGHANI, M. Sexual orientation, labour earnings, and household income in Canada. Journal of Labor Research, v. 39, n. 1, p. 41-55, 2017.

DINARDO, J.; FORTIN, N. M.; LEMIEUX, T. Labor market institutions and the distribution of wages, 1973-1992: a semiparametric approach. Econometrica, v. 64, n. 5, p. 1001-1044, 1996.

DRYDAKIS, N. Sexual orientation discrimination in the labour market. Labour Economics, v. 16, n. 4, p. 364-372, 2009.

DRYDAKIS, N. Women's sexual orientation and labour market outcomes in Greece. Feminist Economics, v. 17, n. 1, p. 89-117, 2011.

DRYDAKIS, N. Sexual orientation and labor market outcomes. IZA World of Labor 111, 2014.

DRYDAKIS, N. Sexual orientation discrimination in the United Kingdom's labour market: a field experiment. Human Relations, v. 68, n. 11, p. 1769-1796, 2015. 
FIRPO, S.; FORTIN, N.; LEMIEUX, T. Decomposing wage distributions using recentered influence function regressions. Mimeo. University of British Columbia, 2007.

FIRPO, S.; FORTIN, N.; LEMIEUX, T. Unconditional quantile regressions. Econometrica, v. 77, n. 3, p. 953-973, 2009.

INSTITUTO BRASILEIRO DE GEOGRAFIA E ESTATÍSTICA. Pesquisa Nacional por Amostra de Domicílios Contínua. Notas Metodológicas, Rio de Janeiro, v. 1, 2014.

INSTITUTO BRASILEIRO DE GEOGRAFIA E ESTATÍSTICA. Pesquisa Nacional por Amostra de Domicílios Contínua. Notas Técnicas, Versão 1.5. Rio de Janeiro, 2018a.

INSTITUTO BRASILEIRO DE GEOGRAFIA E ESTATÍSTICA. Deflacionamento dos Rendimentos do Trabalho dos Trimestres Móveis da PNAD Contínua. Notas Técnicas, Rio de Janeiro, 2018b.

INSTITUTO BRASILEIRO DE GEOGRAFIA E ESTATÍSTICA. Pesquisa Nacional por Amostra de Domicílios Contínua. Notas Técnicas, Versão 1.5. Rio de Janeiro, 2019.

GORISCH, P. Reconhecimento dos direitos humanos LGBT. De Stonewall à ONU. Curitiba: Appris, 2014.

HAMPEL, F. R.; RONCHETTI, E. M.; ROUSSEEUW, P. J.; STAHEL, W. A. Robust statistics: the approach based on influence functions. Wiley-Blackwell, 2005.

HUMPERT, S. Somewhere over the rainbow: sexual orientation and earnings in Germany. International Journal of Manpower, v. 37, n. 1, p. 69-98, 2016.

JACINTO, P.; FRIO, G.; UHR, D.; UHR, J. Z. Offer of work and sexual orientation: evidence of Brazil. The Empirical Economics Letters, v. 16, n. 7, p. 663-667, 2017.

JEPSEN, L. K. Comparing the earnings of cohabiting lesbians, cohabiting heterosexual women, and married women: evidence from the 2000 Census. Industrial Relations, v. 46, n. 4, p. 699-727, 2007.

KLAWITTER, M. M.; FLATT, V. The effects of state and local anti-discrimination policies on earnings for gays and lesbians. Journal of Policy Analysis and Management, v. 17, n. 4, p. 658-686, 1998.

LAURENT, T.; MIHOUBI, F. Sexual orientation and wage discrimination in france: the hidden side of the rainbow. Journal of Labour Research, v. 33, n. 4, p. 487-527, 2012.

MINCER, J. Schooling, experience and earning. New York: Columbia University Press, 1974.

PATACCHINI, E.; RAGUSA, G.; ZENOU, Y. Unexplored dimensions of discrimination in Europe: homosexuality and physical appearance. Journal of Population Economics, v. 28, p. 1045-1073, 2015.

OAXACA, R. Male-female wage differentials in urban labour markets. International Economic Review, v. 14, n. 3, p. 693-709, 1973. 
Daniel Suliano, Alexsandre Lira Cavalcante, Luciana Rodrigues

OLSEN, C. S. L. D. A comunidade LGBT na Dinamarca: a luta continua? A promoção dos direitos da comunidade lgbt num estado de bem-estar. In: MUNDO afora. Políticas de combate à violência e à discriminação contra pessoas LGBT. Brasília, 2015.

OZTURK, M. B. Sexual orientation discrimination: exploring the experiences of lesbian, gay and bisexual employees in Turkey. Human Relations, v. 64, n. 8, p. 1099-1118, 2011.

PEPLAU, L. A.; FINGERHUT, A. The paradox of the lesbian worker. Journal of Social Issues, v. 60, p. 719-735, 2004.

PLUG, E.; BERKHOUT, P. H. G. Sexual orientation, disclosure and earnings. 2008. (IZA Discussion Paper, 3.290).

RIACH, P. A.; RICH, J. Field experiments of discrimination in the market place. The Economic Journal, v. 112, n. 483, p. 480-518, 2002.

SAGARRA, L. Direitos LGBT e crimes de ódio na "Nação Arco-Íris". In: MUNDO Afora. Políticas de combate à violência e à discriminação contra pessoas LGBT. Brasília, 2015.

SULIANO, D.; IRFFI, G.; CORRÊA, M. V.; CAVACALNTE, A. OLIVEIRA, J. Sexual orientation and wage differentials in brazilian labour market. Economia Aplicada, v. 20, n. 3, p. 195-221, 2016.

SULIANO, D.; IRFFI, G. Orientação sexual e alocação eficiente de mão-de-obra. In: ENCONTRO NACIONAL DA ABET, 16, Salvador, 2019. Anais...

TEBALDI, E.; ELMSLIE, B. Sexual orientation and labour supply. Applied Economics, v. 38, n. 5, p. 549-562, 2006.

UENO, K.; ROACH, T.; PENA-TALAMANTES, A. E. Sexual orientation and gender typicality of the occupation in young adulthood. Social Forces, v. 92, n. 1, p. 81-108, 2013.

WEICHSELBAUMER, D. Sexual orientation discrimination in hiring. Labour Economics, v. 10, n. 6, p. 629-642, 2003. 


\section{Appendix 1}

\section{Unconditional quantile regressions}

Table A.1.1

Estimates unconditional quantile regressions - Men

\begin{tabular}{|c|c|c|c|c|c|c|c|c|}
\hline \multirow[b]{2}{*}{ Variables } & \multicolumn{2}{|c|}{ OLS } & \multicolumn{2}{|r|}{ q10 } & \multicolumn{2}{|r|}{ q50 } & \multicolumn{2}{|r|}{ q90 } \\
\hline & Gay couple & Hetero couple & Gay couple & Hetero couple & $\begin{array}{c}\text { Gay } \\
\text { couple }\end{array}$ & $\begin{array}{l}\text { Hetero } \\
\text { couple }\end{array}$ & $\begin{array}{c}\text { Gay } \\
\text { couple }\end{array}$ & $\begin{array}{l}\text { Hetero } \\
\text { couple }\end{array}$ \\
\hline \multirow{2}{*}{$\begin{array}{l}\text { Years of } \\
\text { schooling }\end{array}$} & $0.0582 * * *$ & 0.0556 *** & 0.0431 & $0.0527 * * *$ & 0.0508 & $0.0472 * * *$ & 0.0143 & $0.0885^{* * * *}$ \\
\hline & $(0.0182)$ & $(0.000420)$ & $(0.0371)$ & $(0.00119)$ & $(0.0312)$ & $(0.000550)$ & $(0.0408)$ & $(0.00136)$ \\
\hline \multirow{2}{*}{ White } & $0.264 * *$ & $0.123 * * *$ & 0.126 & $0.0932 * * *$ & 0.232 & $0.0923 * * *$ & $0.599 * *$ & $0.236 * * *$ \\
\hline & $(0.107)$ & $(0.00300)$ & $(0.173)$ & $(0.00761)$ & $(0.161)$ & $(0.00354)$ & $(0.302)$ & $(0.00862)$ \\
\hline \multirow{2}{*}{ Family size } & $-0.162 * *$ & $-0.00785^{* * * *}$ & -0.0438 & $-0.0335^{* * *}$ & -0.0130 & $-0.00680 * * *$ & -0.0767 & 0.0106 *** \\
\hline & $(0.0784)$ & $(0.00106)$ & $(0.143)$ & $(0.00300)$ & $(0.117)$ & $(0.00103)$ & $(0.158)$ & $(0.00242)$ \\
\hline \multirow{2}{*}{ Age } & $0.0696 * * *$ & $0.0269 * * *$ & -0.00634 & $0.0355^{* * * *}$ & $0.0936 * *$ & $0.0279 * * *$ & $0.129 * *$ & $0.0262 * * *$ \\
\hline & $(0.0252)$ & $(0.000772)$ & $(0.0517)$ & $(0.00219)$ & $(0.0454)$ & $(0.000911)$ & $(0.0602)$ & $(0.00178)$ \\
\hline \multirow{2}{*}{$A g e^{2}$} & $-0.000724 * *$ & $-0.000223 * * *$ & 0.000162 & $-0.000374 * * *$ & $-0.000984 *$ & $-0.000257 * * *$ & $-0.00135^{*}$ & $-0.000104 * * *$ \\
\hline & $(0.000293)$ & $(0.000009)$ & $(0.000600)$ & $(0.000025)$ & $(0.000545)$ & $(0.000010)$ & $(0.000795)$ & $(0.000020)$ \\
\hline \multirow{2}{*}{ Tenure } & 0.0990 & $0.0956^{* * *}$ & 0.172 & $1.122 * * *$ & -0.685 & $-0.0691 * * *$ & 0.330 & $-0.385 * * *$ \\
\hline & $(0.264)$ & $(0.0151)$ & $(0.981)$ & $(0.0527)$ & $(0.844)$ & $(0.0164)$ & $(1.135)$ & $(0.0268)$ \\
\hline \multirow{2}{*}{ Tenure $^{2}$} & 0.00865 & $-0.00892 * * *$ & 0.0103 & $-0.192 * * *$ & 0.133 & $0.0237 * * *$ & -0.0296 & $0.0742 * * *$ \\
\hline & $(0.0482)$ & $(0.00257)$ & $(0.165)$ & $(0.00883)$ & $(0.151)$ & $(0.00290)$ & $(0.199)$ & $(0.00473)$ \\
\hline \multirow{2}{*}{ Formal } & $0.313^{* * *}$ & $0.174 * * *$ & 0.341 & $0.617 * * *$ & $0.375^{*}$ & $0.144 * * *$ & 0.234 & $-0.0447 * * *$ \\
\hline & $(0.132)$ & $(0.00374)$ & $(0.250)$ & $(0.0112)$ & $(0.192)$ & $(0.00421)$ & $(0.252)$ & $(0.0112)$ \\
\hline \multirow{2}{*}{ Labor union } & 0.113 & $0.0307 * * *$ & 0.00961 & $-0.204 * * *$ & $0.390 * * *$ & 0.0576 *** & -0.0805 & $0.190^{* * * *}$ \\
\hline & $(0.107)$ & $(0.00359)$ & $(0.144)$ & $(0.00799)$ & $(0.127)$ & $(0.00385)$ & $(0.365)$ & $(0.00988)$ \\
\hline \multirow{2}{*}{$\begin{array}{l}\text { A private-sector } \\
\text { employee }\end{array}$} & 0.123 & 0.0120 *** & 0.0550 & $0.365^{* * *}$ & -0.103 & $-0.0487 * * *$ & 0.381 & $-0.146^{* * *}$ \\
\hline & $(0.139)$ & $(0.00388)$ & $(0.234)$ & $(0.0108)$ & $(0.199)$ & $(0.00397)$ & $(0.267)$ & $(0.00934)$ \\
\hline \multirow{2}{*}{$\begin{array}{l}\text { A public-sector } \\
\text { employee }\end{array}$} & $0.377^{* *}$ & $0.245^{* * *}$ & -0.137 & $0.401 * * *$ & 0.142 & $0.137 * * *$ & 0.448 & $0.447 * * *$ \\
\hline & $(0.185)$ & $(0.00950)$ & $(0.219)$ & $(0.0132)$ & $(0.291)$ & $(0.00768)$ & $(0.698)$ & $(0.0357)$ \\
\hline \multirow{2}{*}{ Employer } & $0.508^{* *}$ & 0.460 **** & 0.0976 & $0.375^{* * * *}$ & 0.503 & $0.307 * * *$ & $1.250^{*}$ & $0.937 * * *$ \\
\hline & $(0.217)$ & $(0.00741)$ & $(0.235)$ & $(0.0130)$ & $(0.312)$ & $(0.00764)$ & $(0.636)$ & $(0.0284)$ \\
\hline \multirow{2}{*}{ Industry } & -0.145 & $-0.0220 * * *$ & -0.568 & $-0.103 * * *$ & 0.481 & 0.00426 & -0.608 & $-0.0229 *$ \\
\hline & $(0.177)$ & $(0.00407)$ & $(0.378)$ & $(0.00820)$ & $(0.316)$ & $(0.00533)$ & $(0.420)$ & $(0.0119)$ \\
\hline \multirow{2}{*}{ Commerce } & -0.188 & $-0.0948 * * *$ & $-0.596 *$ & $-0.0401 * * *$ & 0.116 & $-0.0872 * * *$ & $-0.759 *$ & $-0.186 * * *$ \\
\hline & $(0.168)$ & $(0.00430)$ & $(0.354)$ & $(0.00937)$ & $(0.279)$ & $(0.00555)$ & $(0.440)$ & $(0.0111)$ \\
\hline \multirow{2}{*}{$\begin{array}{l}\text { Acommodation } \\
\text { and food }\end{array}$} & -0.244 & $-0.250 * * *$ & $-1.000 * *$ & $-0.212 * * *$ & 0.240 & $-0.224 * * *$ & 0.240 & $-0.410 * * *$ \\
\hline & $(0.207)$ & $(0.00882)$ & $(0.483)$ & $(0.0240)$ & $(0.328)$ & $(0.0107)$ & $(0.578)$ & $(0.0212)$ \\
\hline \multirow{2}{*}{ Information } & 0.0104 & 0.00206 & -0.565 & $-0.0231 * * *$ & 0.314 & $-0.0368 * * *$ & -0.0406 & $0.144 * * *$ \\
\hline & $(0.175)$ & $(0.00564)$ & $(0.359)$ & $(0.00833)$ & $(0.302)$ & $(0.00770)$ & $(0.496)$ & $(0.0178)$ \\
\hline \multirow{3}{*}{$\begin{array}{l}\text { Public } \\
\text { administration, } \\
\text { defense, health } \\
\text { insurance }\end{array}$} & 0.139 & $0.115^{* * * *}$ & -0.429 & $-0.0207 * *$ & 0.107 & $0.0209^{* *}$ & 0.846 & $0.329 * * *$ \\
\hline & $(0.277)$ & $(0.0102)$ & $(0.388)$ & $(0.00978)$ & $(0.390)$ & $(0.00920)$ & $(0.823)$ & $(0.0423)$ \\
\hline & -0.0297 & $-0.111^{* * * *}$ & $-0.643 *$ & 0.0147 & 0.268 & $-0.111^{* * *}$ & 0.195 & $-0.370 * * *$ \\
\hline
\end{tabular}




\begin{tabular}{|c|c|c|c|c|c|c|c|c|}
\hline \multirow[b]{2}{*}{ Variables } & \multicolumn{2}{|r|}{ OLS } & \multicolumn{2}{|r|}{ q10 } & \multicolumn{2}{|r|}{ q50 } & \multicolumn{2}{|c|}{ q90 } \\
\hline & Gay couple & Hetero couple & Gay couple & Hetero couple & $\begin{array}{c}\text { Gay } \\
\text { couple } \\
\end{array}$ & $\begin{array}{l}\text { Hetero } \\
\text { couple } \\
\end{array}$ & $\begin{array}{c}\text { Gay } \\
\text { couple }\end{array}$ & $\begin{array}{l}\text { Hetero } \\
\text { couple } \\
\end{array}$ \\
\hline $\begin{array}{l}\text { Education, } \\
\text { human health. } \\
\text { social services }\end{array}$ & $(0.194)$ & $(0.00964)$ & $(0.369)$ & (0.00958) & $(0.329)$ & $(0.0102)$ & $(0.645)$ & $(0.0370)$ \\
\hline \multirow{2}{*}{ Other services } & 0.112 & $-0.112 * * *$ & -0.587 & $0.111 * * *$ & $0.679^{* *} *$ & $-0.0776^{* * *}$ & -0.239 & $-0.411^{* * *}$ \\
\hline & $(0.185)$ & $(0.00916)$ & $(0.383)$ & $(0.0193)$ & $(0.312)$ & $(0.0101)$ & $(0.458)$ & $(0.0275)$ \\
\hline \multirow{2}{*}{$\begin{array}{l}\text { Directors and } \\
\text { managers }\end{array}$} & 0.520 & $0.402 * * *$ & $0.765^{*}$ & -0.000627 & $0.985^{* *}$ & $0.274 * * *$ & -0.560 & $1.058 * * *$ \\
\hline & $(0.340)$ & $(0.00732)$ & $(0.452)$ & $(0.0119)$ & $(0.386)$ & $(0.00759)$ & $(0.838)$ & $(0.0293)$ \\
\hline \multirow{2}{*}{$\begin{array}{l}\text { Science and } \\
\text { intelectual } \\
\text { occupations }\end{array}$} & 0.558 & $0.693 * * *$ & $0.785^{*}$ & $-0.0610 * * *$ & $0.789^{* *} *$ & $0.369 * * *$ & -0.0894 & $2.213 * * *$ \\
\hline & $(0.347)$ & $(0.00809)$ & $(0.421)$ & $(0.0108)$ & $(0.384)$ & $(0.00765)$ & $(0.736)$ & $(0.0426)$ \\
\hline \multirow{4}{*}{$\begin{array}{l}\text { Mid-level } \\
\text { technicians and } \\
\text { professionals } \\
\text { Administrative } \\
\text { support workers }\end{array}$} & 0.314 & $0.277 * * *$ & $0.783 *$ & $0.0928 * * *$ & $0.624^{*}$ & $0.281 * * *$ & -0.578 & $0.483 * * *$ \\
\hline & $(0.341)$ & $(0.00602)$ & $(0.412)$ & (0.00864) & $(0.349)$ & $(0.00779)$ & $(0.808)$ & $(0.0217)$ \\
\hline & -0.0507 & 0.00846 & 0.606 & 0.0111 & 0.184 & $0.0614 * * *$ & -1.336 & $-0.107 * * *$ \\
\hline & $(0.331)$ & $(0.00701)$ & $(0.487)$ & $(0.00977)$ & $(0.327)$ & $(0.00870)$ & $(0.892)$ & $(0.0248)$ \\
\hline \multirow{2}{*}{$\begin{array}{l}\text { Service } \\
\text { workers, } \\
\text { shopkeepers } \\
\text { and markets }\end{array}$} & 0.201 & 0.00333 & 0.556 & $0.105^{* * * *}$ & 0.165 & -0.0110 & -0.633 & $-0.0736 * * *$ \\
\hline & $(0.327)$ & $(0.00496)$ & $(0.485)$ & (0.00999) & $(0.358)$ & $(0.00682)$ & $(0.677)$ & $(0.0146)$ \\
\hline \multirow{2}{*}{ Factory worker } & 0.183 & $0.113 * * *$ & 0.734 & $0.458 * * *$ & -0.0602 & $0.0946 * * *$ & -0.684 & $-0.139 * * *$ \\
\hline & $(0.319)$ & $(0.00387)$ & $(0.520)$ & $(0.0102)$ & $(0.410)$ & $(0.00501)$ & $(0.650)$ & $(0.00785)$ \\
\hline \multirow{2}{*}{$\begin{array}{l}\text { Basic } \\
\text { occupations }\end{array}$} & 0.0397 & $-0.147 * * *$ & 0.275 & $-0.0549 * * *$ & 0.00777 & $-0.272 * * *$ & -0.606 & -0.00153 \\
\hline & $(0.341)$ & $(0.00417)$ & $(0.667)$ & $(0.0117)$ & $(0.379)$ & $(0.00492)$ & $(0.646)$ & $(0.00789)$ \\
\hline \multirow{2}{*}{ Southeast } & $0.204 *$ & $0.248 * * *$ & -0.127 & $0.549 * * *$ & 0.178 & $0.248 * * *$ & $0.718 * *$ & $0.0544 * * *$ \\
\hline & $(0.109)$ & $(0.00335)$ & $(0.217)$ & $(0.0119)$ & $(0.156)$ & $(0.00440)$ & $(0.347)$ & $(0.00884)$ \\
\hline \multirow{2}{*}{ South } & 0.106 & $0.331 * * *$ & 0.0467 & $0.634 * * *$ & 0.0389 & $0.366^{* * * *}$ & 0.386 & $0.0768 * * *$ \\
\hline & $(0.135)$ & $(0.00422)$ & $(0.235)$ & $(0.0126)$ & $(0.187)$ & $(0.00528)$ & $(0.364)$ & $(0.0113)$ \\
\hline \multirow{2}{*}{ Center-west } & 0.174 & $0.390 * * *$ & -0.128 & $0.707 * * * *$ & 0.201 & $0.377 * * *$ & 0.599 & $0.264 * * *$ \\
\hline & $(0.177)$ & $(0.00439)$ & $(0.295)$ & $(0.0128)$ & $(0.249)$ & $(0.00623)$ & $(0.441)$ & $(0.0134)$ \\
\hline \multirow{2}{*}{ Urbain area } & 0.139 & $0.178 * * *$ & 0.332 & $0.377 * * *$ & 0.0798 & $0.178 * * *$ & 0.521 & $0.0501 * * *$ \\
\hline & $(0.154)$ & $(0.00354)$ & $(0.435)$ & $(0.0106)$ & $(0.249)$ & $(0.00400)$ & $(0.644)$ & $(0.00891)$ \\
\hline \multirow{2}{*}{$\begin{array}{l}\text { Metropolitan } \\
\text { area }\end{array}$} & $0.177^{*}$ & $0.0958 * * *$ & 0.154 & $0.163 * * *$ & 0.230 & $0.0508 * * *$ & 0.0167 & $0.153 * * *$ \\
\hline & $(0.0973)$ & $(0.00302)$ & $(0.142)$ & $(0.00665)$ & $(0.144)$ & $(0.00377)$ & $(0.265)$ & $(0.0112)$ \\
\hline \multirow{2}{*}{2012} & -0.0607 & $0.0117 * * *$ & 0.107 & -0.000841 & -0.115 & $-0.0215^{* * *}$ & -0.180 & $0.0910 * * *$ \\
\hline & $(0.132)$ & $(0.00374)$ & $(0.218)$ & $(0.00964)$ & $(0.232)$ & $(0.00426)$ & $(0.344)$ & $(0.00976)$ \\
\hline \multirow{2}{*}{2013} & 0.0565 & $0.0296 * * *$ & 0.124 & $0.0383 * * *$ & 0.207 & -0.00104 & -0.241 & $0.0765^{* * * *}$ \\
\hline & $(0.121)$ & $(0.00362)$ & $(0.191)$ & $(0.00915)$ & $(0.170)$ & $(0.00416)$ & $(0.325)$ & $(0.00962)$ \\
\hline \multirow{2}{*}{2014} & -0.0600 & $0.0405^{* * *}$ & 0.0123 & $0.0558^{* * * *}$ & 0.0776 & $0.0330 * * *$ & -0.483 & $0.0597 * * *$ \\
\hline & $(0.109)$ & $(0.00354)$ & $(0.163)$ & $(0.00945)$ & $(0.136)$ & $(0.00371)$ & $(0.371)$ & $(0.00938)$ \\
\hline \multirow{2}{*}{ Constant } & -0.831 & $0.162 * * *$ & -0.358 & $-2.739 * * *$ & -0.939 & $0.480 * * *$ & -0.519 & $1.536 * * *$ \\
\hline & $(0.691)$ & $(0.0264)$ & $(1.723)$ & $(0.102)$ & $(1.435)$ & $(0.0266)$ & $(1.920)$ & $(0.0553)$ \\
\hline Observations & 305 & 276,338 & 305 & 276,338 & 305 & 276,338 & 305 & 276,338 \\
\hline$R$-squared & 0.504 & 0.449 & 0.160 & 0.208 & 0.438 & 0.313 & 0.231 & 0.242 \\
\hline
\end{tabular}

Source: Elaborated by the authors from the Continuous PNAD.

Robust standard errors in parentheses. $* * * \mathrm{p}<0.01, * * \mathrm{p}<0.05, * \mathrm{p}<0.1$. 
Table A.1.2

Estimates unconditional quantile regressions - Women

\begin{tabular}{|c|c|c|c|c|c|c|c|c|}
\hline \multirow[b]{2}{*}{ Variables } & \multicolumn{2}{|c|}{ OLS } & \multicolumn{2}{|c|}{ q10 } & \multicolumn{2}{|c|}{ q50 } & \multicolumn{2}{|c|}{ q90 } \\
\hline & $\begin{array}{c}\text { Lesbian } \\
\text { couple }\end{array}$ & Hetero couple & $\begin{array}{c}\text { Lesbian } \\
\text { couple }\end{array}$ & Hetero couple & $\begin{array}{c}\text { Lesbian } \\
\text { couple }\end{array}$ & Hetero couple & $\begin{array}{c}\text { Lesbian } \\
\text { couple }\end{array}$ & $\begin{array}{l}\text { Hetero } \\
\text { couple }\end{array}$ \\
\hline \multirow{2}{*}{$\begin{array}{l}\text { Years of } \\
\text { schooling }\end{array}$} & $0.0640 * * *$ & $0.0555^{* * * *}$ & 0.0332 & $0.0757 * * *$ & $0.0597 * * *$ & $0.0432 * * *$ & $0.0931 * * *$ & $0.0702 * * *$ \\
\hline & $(0.0132)$ & $(0.00113)$ & $(0.0252)$ & $(0.00390)$ & $(0.0160)$ & $(0.00132)$ & $(0.0354)$ & $(0.00267)$ \\
\hline \multirow{2}{*}{ White } & -0.0315 & $0.129 * * *$ & -0.0668 & $0.0710^{* * * *}$ & -0.0184 & $0.0953 * * *$ & 0.0812 & $0.255^{* * *}$ \\
\hline & $(0.0860)$ & $(0.00724)$ & $(0.130)$ & $(0.0176)$ & $(0.108)$ & $(0.00859)$ & $(0.258)$ & $(0.0192)$ \\
\hline \multirow{2}{*}{ Family size } & -0.0262 & -0.00280 & -0.00745 & $-0.0216^{* *}$ & -0.0189 & -0.00162 & -0.0201 & 0.00414 \\
\hline & $(0.0327)$ & $(0.00247)$ & $(0.0583)$ & $(0.00930)$ & $(0.0440)$ & $(0.00250)$ & $(0.0589)$ & $(0.00466)$ \\
\hline \multirow{2}{*}{ Age } & 0.0111 & $0.0207 * * *$ & -0.00988 & $0.0421 * * *$ & 0.0275 & $0.0196^{* * * *}$ & -0.0508 & $0.0184 * * *$ \\
\hline & $(0.0240)$ & $(0.00221)$ & $(0.0384)$ & $(0.00716)$ & $(0.0268)$ & $(0.00224)$ & $(0.0716)$ & $(0.00400)$ \\
\hline \multirow{2}{*}{$\mathrm{Age}^{2}$} & -0.000040 & $-0.000178 * * *$ & 0.000075 & $-0.000484 * * *$ & -0.000278 & $-0.000186 * * *$ & -0.00104 & -0.000060 \\
\hline & $(0.000311)$ & $(0.000027)$ & $(0.000494)$ & $(0.000083)$ & $(0.000334)$ & $(0.000026)$ & $(0.00100)$ & $(0.000049)$ \\
\hline \multirow{2}{*}{ Tenure } & 0.0345 & -0.0164 & 0.245 & $0.385^{* * * *}$ & -0.632 & $-0.124 * * *$ & -0.302 & $-0.305 * * *$ \\
\hline & $(0.365)$ & $(0.0380)$ & $(0.846)$ & $(0.127)$ & $(0.480)$ & $(0.0426)$ & $(0.788)$ & $(0.0641)$ \\
\hline \multirow{2}{*}{ Tenure $^{2}$} & 0.0116 & $0.0159 * *$ & -0.0157 & $-0.0452 * *$ & 0.129 & $0.0348^{* * *}$ & 0.0484 & $0.0612 * * *$ \\
\hline & $(0.0635)$ & $(0.00642)$ & $(0.142)$ & $(0.0209)$ & $(0.0828)$ & $(0.00712)$ & $(0.140)$ & $(0.0108)$ \\
\hline \multirow{2}{*}{ Formal } & $0.271 * *$ & $0.150 * * *$ & $0.505^{* * *}$ & $0.903^{* * *}$ & $0.261 *$ & $0.0439 * * *$ & -0.00109 & $-0.0743 * * *$ \\
\hline & $(0.114)$ & $(0.00915)$ & $(0.189)$ & $(0.0319)$ & $(0.149)$ & $(0.0113)$ & $(0.247)$ & $(0.0196)$ \\
\hline \multirow{2}{*}{ Labor union } & $0.206 * *$ & $0.0469 * * *$ & -0.0530 & $-0.355^{* * * *}$ & 0.108 & $0.0545 * * *$ & $0.550 *$ & $0.394 * * *$ \\
\hline & $(0.0964)$ & $(0.00917)$ & $(0.0750)$ & $(0.0221)$ & $(0.113)$ & $(0.00807)$ & $(0.326)$ & $(0.0282)$ \\
\hline \multirow{2}{*}{$\begin{array}{l}\text { A private- } \\
\text { sector } \\
\text { employee }\end{array}$} & -0.0552 & $-0.0483 * * *$ & 0.266 & $0.416^{* * *}$ & -0.104 & $-0.160 * * *$ & -0.0357 & $-0.208 * * *$ \\
\hline & $(0.120)$ & $(0.0109)$ & $(0.168)$ & $(0.0319)$ & $(0.149)$ & $(0.0118)$ & $(0.286)$ & $(0.0231)$ \\
\hline \multirow{2}{*}{$\begin{array}{l}\text { A public-sector } \\
\text { employee }\end{array}$} & 0.0569 & $0.188^{* * *}$ & 0.0242 & 0.492 *** & -0.00517 & 0.101 **** & 0.255 & $0.154 * * *$ \\
\hline & $(0.208)$ & $(0.0170)$ & $(0.212)$ & $(0.0370)$ & $(0.218)$ & $(0.0171)$ & $(0.608)$ & $(0.0585)$ \\
\hline \multirow{2}{*}{ Employer } & 0.282 & $0.376^{* * * *}$ & 0.00878 & $0.310^{* * *}$ & 0.164 & $0.266^{* * * *}$ & 0.0395 & $0.683 * * *$ \\
\hline & $(0.250)$ & $(0.0219)$ & $(0.364)$ & $(0.0428)$ & $(0.285)$ & $(0.0203)$ & $(0.613)$ & $(0.0674)$ \\
\hline \multirow{2}{*}{ Industry } & -0.00140 & -0.0211 & 0.290 & 0.00570 & -0.142 & $-0.0299 *$ & 0.243 & -0.0406 \\
\hline & $(0.156)$ & $(0.0157)$ & $(0.268)$ & $(0.0465)$ & $(0.219)$ & $(0.0166)$ & $(0.363)$ & $(0.0337)$ \\
\hline \multirow{2}{*}{ Commerce } & -0.105 & $-0.0229 *$ & 0.0889 & -0.0192 & $-0.350 *$ & 0.00611 & -0.147 & $-0.0609 * *$ \\
\hline & $(0.133)$ & $(0.0137)$ & $(0.227)$ & $(0.0433)$ & $(0.185)$ & $(0.0148)$ & $(0.332)$ & $(0.0258)$ \\
\hline \multirow{2}{*}{$\begin{array}{l}\text { Acommodation } \\
\text { and food }\end{array}$} & -0.211 & $-0.0397 * *$ & -0.0861 & 0.127 *** & -0.261 & $-0.0537 * * *$ & -0.529 & $-0.101 * * *$ \\
\hline & $(0.169)$ & $(0.0156)$ & $(0.283)$ & $(0.0503)$ & $(0.256)$ & $(0.0179)$ & $(0.323)$ & $(0.0324)$ \\
\hline \multirow{2}{*}{ Information } & -0.0283 & $0.143 * * *$ & 0.224 & $0.102 * * *$ & -0.0156 & $0.0721 * * *$ & -0.269 & $0.345^{* * *}$ \\
\hline & $(0.141)$ & $(0.0150)$ & $(0.188)$ & $(0.0362)$ & $(0.216)$ & $(0.0173)$ & $(0.397)$ & $(0.0436)$ \\
\hline \multirow{2}{*}{$\begin{array}{l}\text { Public } \\
\text { administration, } \\
\text { defense, health } \\
\text { insurance }\end{array}$} & 0.252 & $0.163 * * *$ & $0.359^{* *}$ & $0.0830 * *$ & 0.341 & $0.0388^{*}$ & -0.221 & $0.445^{* * *}$ \\
\hline & $(0.207)$ & $(0.0203)$ & $(0.164)$ & $(0.0378)$ & $(0.289)$ & $(0.0219)$ & $(0.681)$ & $(0.0675)$ \\
\hline \multirow{2}{*}{$\begin{array}{l}\text { Education, } \\
\text { human health. } \\
\text { social services }\end{array}$} & -0.00648 & $-0.0314 * *$ & 0.180 & $0.127 * * *$ & -0.0950 & 0.0221 & -0.439 & $-0.309 * * *$ \\
\hline & $(0.171)$ & $(0.0158)$ & $(0.179)$ & $(0.0359)$ & $(0.247)$ & $(0.0199)$ & $(0.471)$ & $(0.0462)$ \\
\hline \multirow{3}{*}{ Other services } & 0.137 & $0.124 * * *$ & 0.198 & $0.428 * * *$ & 0.137 & $0.126^{* * * *}$ & -0.137 & $-0.0767 * *$ \\
\hline & $(0.176)$ & $(0.0168)$ & $(0.328)$ & $(0.0503)$ & $(0.279)$ & $(0.0212)$ & $(0.522)$ & $(0.0352)$ \\
\hline & $0.518^{* * * *}$ & $0.393 * * *$ & -0.242 & -0.00382 & $0.871 * * *$ & $0.406 * * *$ & $0.861 *$ & $0.683^{* * * *}$ \\
\hline
\end{tabular}




\begin{tabular}{|c|c|c|c|c|c|c|c|c|}
\hline \multirow[b]{2}{*}{ Variables } & \multicolumn{2}{|c|}{ OLS } & \multicolumn{2}{|c|}{ q10 } & \multicolumn{2}{|c|}{$\mathbf{q 5 0}$} & \multicolumn{2}{|c|}{ q90 } \\
\hline & $\begin{array}{c}\text { Lesbian } \\
\text { couple }\end{array}$ & Hetero couple & $\begin{array}{c}\text { Lesbian } \\
\text { couple }\end{array}$ & Hetero couple & $\begin{array}{c}\text { Lesbian } \\
\text { couple }\end{array}$ & Hetero couple & $\begin{array}{c}\text { Lesbian } \\
\text { couple }\end{array}$ & $\begin{array}{l}\text { Hetero } \\
\text { couple }\end{array}$ \\
\hline $\begin{array}{l}\text { Directors and } \\
\text { managers }\end{array}$ & $(0.200)$ & $(0.0236)$ & $(0.330)$ & $(0.0546)$ & $(0.296)$ & $(0.0212)$ & $(0.517)$ & $(0.0693)$ \\
\hline \multirow{2}{*}{$\begin{array}{l}\text { Science and } \\
\text { intelectual } \\
\text { occupations }\end{array}$} & $0.725^{* * *}$ & $0.626^{* * *}$ & -0.0732 & $-0.114 * *$ & $1.016 * * *$ & $0.554 * * *$ & $1.283^{* *}$ & $1.344 * * *$ \\
\hline & $(0.160)$ & $(0.0202)$ & $(0.210)$ & $(0.0510)$ & $(0.246)$ & $(0.0187)$ & $(0.507)$ & $(0.0531)$ \\
\hline \multirow{2}{*}{$\begin{array}{l}\text { Mid-level } \\
\text { technicians } \\
\text { and } \\
\text { professionals }\end{array}$} & $0.380^{* * *}$ & $0.233^{* * *} *$ & -0.0777 & 0.0745 & 0.741 *** & 0.321 *** & 0.216 & $0.248 * * *$ \\
\hline & $(0.166)$ & $(0.0199)$ & $(0.229)$ & $(0.0492)$ & $(0.262)$ & $(0.0223)$ & $(0.464)$ & $(0.0488)$ \\
\hline \multirow{2}{*}{$\begin{array}{l}\text { Administrative } \\
\text { support } \\
\text { workers }\end{array}$} & 0.146 & $0.0664 * * *$ & -0.212 & -0.00151 & $0.499 *$ & $0.240 * * *$ & 0.221 & $-0.126^{* * * *}$ \\
\hline & $(0.153)$ & $(0.0185)$ & $(0.234)$ & $(0.0489)$ & $(0.263)$ & $(0.0220)$ & $(0.425)$ & $(0.0441)$ \\
\hline \multirow{2}{*}{$\begin{array}{l}\text { Service } \\
\text { workers, } \\
\text { shopkeepers } \\
\text { and markets }\end{array}$} & 0.0727 & -0.00759 & -0.257 & 0.0536 & $0.521 * *$ & 0.00479 & 0.279 & $-0.0565 *$ \\
\hline & $(0.138)$ & $(0.0176)$ & $(0.253)$ & $(0.0505)$ & $(0.202)$ & $(0.0177)$ & $(0.338)$ & $(0.0337)$ \\
\hline \multirow{2}{*}{$\begin{array}{l}\text { Factory } \\
\text { worker }\end{array}$} & 0.201 & $-0.0648 * * *$ & -0.158 & -0.0195 & $0.415^{*}$ & -0.0325 & 0.257 & $-0.124 * * *$ \\
\hline & $(0.169)$ & $(0.0201)$ & $(0.295)$ & $(0.0657)$ & $(0.217)$ & $(0.0218)$ & $(0.346)$ & $(0.0318)$ \\
\hline \multirow{2}{*}{$\begin{array}{l}\text { Basic } \\
\text { occupations }\end{array}$} & 0.0818 & 0.0152 & -0.221 & $0.367 * * *$ & 0.290 & $-0.0553 * * *$ & 0.325 & $-0.110 * * *$ \\
\hline & $(0.144)$ & $(0.0169)$ & $(0.320)$ & $(0.0525)$ & $(0.199)$ & $(0.0164)$ & $(0.335)$ & $(0.0285)$ \\
\hline \multirow{2}{*}{ Southeast } & $0.326^{* * * *}$ & $0.237 * * *$ & $0.283 * *$ & $0.560^{* * *}$ & 0.206 & $0.206^{* * * *}$ & $0.604 * *$ & $0.102^{* * * *}$ \\
\hline & $(0.0899)$ & $(0.00812)$ & $(0.142)$ & $(0.0226)$ & $(0.132)$ & $(0.00961)$ & $(0.237)$ & $(0.0215)$ \\
\hline \multirow{2}{*}{ South } & $0.481 * * *$ & $0.302 * * *$ & $0.519 * * *$ & $0.662 * * *$ & 0.285 & $0.326 * * *$ & 0.160 & 0.0150 \\
\hline & $(0.111)$ & $(0.00974)$ & $(0.155)$ & $(0.0267)$ & $(0.179)$ & $(0.0108)$ & $(0.348)$ & $(0.0270)$ \\
\hline \multirow{2}{*}{ Center-west } & $0.511^{* * *} *$ & $0.335^{* * *}$ & $0.603 * * *$ & $0.657^{* * * *}$ & $0.463^{* *}$ & $0.275^{* * * *}$ & $0.745^{* *}$ & $0.315^{* * * *}$ \\
\hline & $(0.135)$ & $(0.0105)$ & $(0.164)$ & $(0.0269)$ & $(0.198)$ & $(0.0128)$ & $(0.369)$ & $(0.0286)$ \\
\hline \multirow{2}{*}{ Urban area } & -0.118 & $0.189^{* * *}$ & -0.266 & $0.577^{*} * *$ & 0.0575 & $0.0822 * * *$ & -0.257 & $0.115^{* * *}$ \\
\hline & $(0.168)$ & $(0.0108)$ & $(0.365)$ & $(0.0375)$ & $(0.209)$ & $(0.0114)$ & $(0.373)$ & $(0.0209)$ \\
\hline \multirow{2}{*}{$\begin{array}{l}\text { Metropolitan } \\
\text { area }\end{array}$} & 0.100 & $0.133^{* * * *}$ & 0.165 & $0.249^{* * *}$ & 0.0957 & $0.0642 * * *$ & 0.151 & $0.223^{* * *} *$ \\
\hline & $(0.0871)$ & $(0.00667)$ & $(0.139)$ & $(0.0171)$ & $(0.104)$ & $(0.00795)$ & $(0.223)$ & $(0.0192)$ \\
\hline \multirow{2}{*}{2012} & -0.165 & 0.00717 & -0.142 & -0.00298 & -0.195 & -0.00371 & 0.210 & $0.0544 * *$ \\
\hline & $(0.117)$ & $(0.00935)$ & $(0.197)$ & $(0.0298)$ & $(0.151)$ & $(0.0107)$ & $(0.352)$ & $(0.0216)$ \\
\hline \multirow{2}{*}{2013} & -0.00871 & $0.0166^{*}$ & 0.0484 & $0.0790 * * *$ & -0.0395 & -0.00346 & 0.239 & -0.00643 \\
\hline & $(0.113)$ & $(0.00871)$ & $(0.186)$ & $(0.0241)$ & $(0.167)$ & $(0.00953)$ & $(0.236)$ & $(0.0205)$ \\
\hline \multirow{2}{*}{2014} & -0.0529 & $0.0225 * * *$ & -0.109 & $0.0890 * * *$ & -0.0223 & 0.00565 & 0.0433 & 0.00512 \\
\hline & $(0.0962)$ & $(0.00829)$ & $(0.138)$ & $(0.0237)$ & $(0.121)$ & $(0.00976)$ & $(0.244)$ & $(0.0204)$ \\
\hline \multirow{2}{*}{ Constant } & 0.440 & 0.108 & 0.153 & $-3.155^{* * *} *$ & 0.626 & $0.587 * * *$ & 2.777 & $1.595^{* * * *}$ \\
\hline & $(0.701)$ & $(0.0705)$ & $(1.472)$ & $(0.263)$ & $(0.797)$ & $(0.0774)$ & (1.693) & $(0.125)$ \\
\hline Observations & 399 & 47,472 & 399 & 47,472 & 399 & 47,472 & 399 & 47,472 \\
\hline$R$-squared & 0.514 & 0.444 & 0.261 & 0.217 & 0.405 & 0.305 & 0.225 & 0.215 \\
\hline
\end{tabular}

Source: Elaborated by the authors based on the Continuous PNAD.

Robust standard errors in parentheses. $* * * \mathrm{p}<0.01, * * \mathrm{p}<0.05, * \mathrm{p}<0.1$. 


\section{Appendix 2}

Decomposing results

Table A.2.1

RIF Decomposition - Men

\begin{tabular}{c|c|c|c|c|c|c|c}
\hline \multirow{2}{*}{ Estimate } & \multicolumn{3}{|c|}{ Expected avarege } & \multicolumn{3}{c}{ Difference between groups } \\
\cline { 2 - 8 } & Gay couples & Hetero couples & Differential & Characteristics & $\%$ & Structural & $\%$ \\
\hline $\mathrm{q} 10$ & $1.7101 * * *$ & $1.1525 * * *$ & $0.5576 * * *$ & $0.3052^{*}$ & $55 \%$ & 0.2523 & $45 \%$ \\
\hline $\mathrm{q} 20$ & $2.0556 * * *$ & $1.5289 * * *$ & $0.5266 * * *$ & $0.6194 * * *$ & $118 \%$ & -0.0928 & $-18 \%$ \\
\hline $\mathrm{q} 30$ & $2.2993 * * *$ & $1.7113^{* * *}$ & $0.5879 * * *$ & $0.8292^{* * *}$ & $141 \%$ & -0.2412 & $-41 \%$ \\
\hline $\mathrm{q} 40$ & $2.5663 * * *$ & $1.9262 * * *$ & $0.6400^{* * *}$ & $0.9127 * * *$ & $143 \%$ & -0.2727 & $-43 \%$ \\
\hline $\mathrm{q} 50$ & $2.7977 * * *$ & $2.1314 * * *$ & $0.6662 * * *$ & $0.8521 * * *$ & $128 \%$ & -0.1858 & $-28 \%$ \\
\hline $\mathrm{q} 60$ & $3.0597 * * *$ & $2.3423 * * *$ & $0.7174 * * *$ & $0.9270^{* * *}$ & $129 \%$ & -0.2096 & $-29 \%$ \\
\hline $\mathrm{q} 70$ & $3.3410^{* * *}$ & $2.6092^{* * *}$ & $0.7318^{* * *}$ & $0.7215^{* * *}$ & $99 \%$ & 0.0103 & $1 \%$ \\
\hline $\mathrm{q} 80$ & $3.6351 * * *$ & $2.9867 * * *$ & $0.6484 * * *$ & $0.8082 * * *$ & $125 \%$ & -0.1597 & $-25 \%$ \\
\hline $\mathrm{q} 90$ & $4.2870^{* * *}$ & $3.6859 * * *$ & $0.6011^{* * *}$ & 0.5360 & $89 \%$ & 0.0650 & $11 \%$ \\
\hline
\end{tabular}

Source: Elaborated by the authors based on the Continuous PNAD.

$* * * \mathrm{p}<0.01, * * \mathrm{p}<0.05, * \mathrm{p}<0.1$

Table A.2.2

RIF Decomposition - Women

\begin{tabular}{c|c|c|c|c|c|c|c}
\hline \multirow{2}{*}{ Estimate } & \multicolumn{3}{|c|}{ Expected avarege } & \multicolumn{3}{c}{ Difference between groups } \\
\cline { 2 - 8 } & $\begin{array}{c}\text { Lesbian } \\
\text { couples }\end{array}$ & Hetero couples & Differential & Characteristics & $\%$ & Structural & $\%$ \\
\hline $\mathrm{q} 10$ & $1.3375^{* * *}$ & $1.1364^{* * *}$ & $0.2011^{* * *}$ & $0.1166^{*}$ & $58 \%$ & 0.0844 & $42 \%$ \\
\hline $\mathrm{q} 20$ & $1.5963^{* * *}$ & $1.5258^{* * *}$ & 0.0705 & $0.1248^{* *}$ & $177 \%$ & -0.0543 & $-77 \%$ \\
\hline $\mathrm{q} 30$ & $1.8035^{* * *}$ & $1.6740^{* * *}$ & $0.1295^{* * *}$ & $0.1135^{* *}$ & $88 \%$ & 0.0159 & $12 \%$ \\
\hline $\mathrm{q} 40$ & $2.0130^{* * *}$ & $1.8412^{* * *}$ & $0.1717^{* * *}$ & $0.1386^{* * *}$ & $81 \%$ & 0.0331 & $19 \%$ \\
\hline $\mathrm{q} 50$ & $2.2216^{* * *}$ & $2.0281^{* * *}$ & $0.1934^{* * *}$ & $0.1197 * *$ & $62 \%$ & 0.0736 & $38 \%$ \\
\hline $\mathrm{q} 60$ & $2.4278^{* * *}$ & $2.2730^{* * *}$ & $0.1548^{* * *}$ & $0.1320^{* *}$ & $85 \%$ & 0.0227 & $15 \%$ \\
\hline $\mathrm{q} 70$ & $2.8283^{* * *}$ & $2.5601^{* * *}$ & $0.2681^{* * *}$ & $0.2489^{* *}$ & $93 \%$ & 0.0191 & $7 \%$ \\
\hline $\mathrm{q} 80$ & $3.2639^{* * *}$ & $2.9955^{* * *}$ & $0.2684^{* * *}$ & 0.0787 & $29 \%$ & $0.1896^{*}$ & $71 \%$ \\
\hline $\mathrm{q} 90$ & $3.9338^{* * *}$ & $3.6927 * * *$ & $0.2410^{*}$ & -0.0320 & $-13 \%$ & 0.2731 & $113 \%$ \\
\hline
\end{tabular}

Source: Elaborated by the authors based on the Continuous PNAD.

$* * * \mathrm{p}<0.01, * * \mathrm{p}<0.05, * \mathrm{p}<0.1$.

Table A.2.3

Characteristic effect decomposition - Men

\begin{tabular}{c|c|c|c|c|c|c|c|c}
\hline Quantis & $\begin{array}{c}\text { Demographic } \\
\text { Characteristics } \\
\text { and human } \\
\text { capital }\end{array}$ & $\%$ & Labor market & $\%$ & $\begin{array}{c}\text { Groups of } \\
\text { primary } \\
\text { activities and } \\
\text { occupations }\end{array}$ & $\%$ & $\begin{array}{c}\text { Geography } \\
\text { and time }\end{array}$ & $\%$ \\
\hline $\mathrm{q} 10$ & 0.1915 & $63 \%$ & 0.0514 & $17 \%$ & -0.0493 & $-16 \%$ & 0.1115 & $37 \%$ \\
\hline $\mathrm{q} 20$ & $0.5180 * * *$ & $84 \%$ & $0.0877 *$ & $14 \%$ & -0.0479 & $-8 \%$ & 0.0615 & $10 \%$ \\
\hline $\mathrm{q} 30$ & 0.1802 & $22 \%$ & $0.0864 *$ & $10 \%$ & $0.2982 *$ & $36 \%$ & $0.2642 * * *$ & $32 \%$ \\
\hline $\mathrm{q} 40$ & 0.2109 & $23 \%$ & $0.1197 * *$ & $13 \%$ & $0.4652 * * *$ & $51 \%$ & 0.1168 & $13 \%$ \\
\hline $\mathrm{q} 50$ & 0.2092 & $25 \%$ & $0.1308 * *$ & $15 \%$ & $0.3507 * * *$ & $41 \%$ & $0.1612 *$ & $19 \%$ \\
\hline $\mathrm{q} 60$ & $0.3959 *$ & $43 \%$ & $0.1292^{* *}$ & $14 \%$ & 0.1589 & $17 \%$ & $0.2429 * *$ & $26 \%$ \\
\hline $\mathrm{q} 70$ & $0.3983 * *$ & $55 \%$ & $0.1865 * *$ & $26 \%$ & -0.0848 & $-12 \%$ & $0.2214 * *$ & $31 \%$ \\
\hline $\mathrm{q} 80$ & $0.6660 * *$ & $82 \%$ & $0.2302 * * *$ & $28 \%$ & -0.2536 & $-31 \%$ & 0.1654 & $20 \%$ \\
\hline $\mathrm{q} 90$ & 0.1982 & $37 \%$ & 0.1772 & $33 \%$ & -0.2281 & $-43 \%$ & $0.3887 *$ & $73 \%$ \\
\hline
\end{tabular}

Source: Elaborated by the authors based on the Continuous PNAD.

$* * * \mathrm{p}<0.01, * * \mathrm{p}<0.05, * \mathrm{p}<0.1$ 
Table A.2.4

Characteristic effect decomposition - Women

\begin{tabular}{|c|c|c|c|c|c|c|c|c|}
\hline Quantis & $\begin{array}{c}\text { Demographic } \\
\text { Characteristics } \\
\text { and human } \\
\text { capital }\end{array}$ & $\%$ & Labor market & $\%$ & $\begin{array}{c}\text { Groups of } \\
\text { primary } \\
\text { activities and } \\
\text { occupations }\end{array}$ & $\%$ & $\begin{array}{c}\text { Geography } \\
\text { and time }\end{array}$ & $\%$ \\
\hline q10 & 0.0734 & $63 \%$ & 0.0358 & $31 \%$ & 0.0071 & $6 \%$ & 0.0003 & $0,3 \%$ \\
\hline $\mathrm{q} 20$ & $0.0729 *$ & $58 \%$ & 0.0129 & $10 \%$ & $0.0395^{*}$ & $32 \%$ & -0.0005 & $-0,4 \%$ \\
\hline $\mathrm{q} 30$ & $0.0862 * *$ & $76 \%$ & -0.0196 & $-17 \%$ & 0.0245 & $22 \%$ & 0.0224 & $19,7 \%$ \\
\hline $\mathrm{q} 40$ & $0,0843^{* *}$ & $61 \%$ & -0.0235 & $-17 \%$ & $0.0601 * *$ & $43 \%$ & 0.0177 & $12,8 \%$ \\
\hline $\mathrm{q} 50$ & $0.0695^{*}$ & $58 \%$ & -0.0180 & $-15 \%$ & $0.0498 * *$ & $42 \%$ & 0.0185 & $15,4 \%$ \\
\hline q60 & 0.0564 & $43 \%$ & -0.0150 & $-11 \%$ & $0.0630 * *$ & $48 \%$ & 0.0275 & $20,8 \%$ \\
\hline $\mathrm{q} 70$ & $0.1751^{* *}$ & $70 \%$ & -0.0175 & $-7 \%$ & $0.0881 *$ & $35 \%$ & 0.0031 & $1,2 \%$ \\
\hline q80 & 0.0713 & $91 \%$ & -0.0176 & $-22 \%$ & 0.0237 & $30 \%$ & 0.0013 & $1,7 \%$ \\
\hline q90 & 0.0290 & $-91 \%$ & -0.0074 & $23 \%$ & -0.0065 & $20 \%$ & -0.0469 & $147,5 \%$ \\
\hline
\end{tabular}

Source: Elaborated by the authors based on the Continuous PNAD.

$* * * \mathrm{p}<0.01, * * \mathrm{p}<0.05, * \mathrm{p}<0.1$

Table A.2.5

Structural effect decomposition - Men

\begin{tabular}{|c|c|c|c|c|c|c|c|c|c|c|}
\hline Quantis & $\begin{array}{c}\text { Demographic } \\
\text { Characteristics } \\
\text { and human } \\
\text { capital }\end{array}$ & $\%$ & $\begin{array}{l}\text { Labor } \\
\text { market }\end{array}$ & $\%$ & $\begin{array}{c}\text { Groups of } \\
\text { primary } \\
\text { activities and } \\
\text { occupations }\end{array}$ & $\%$ & $\begin{array}{c}\text { Geography } \\
\text { and time }\end{array}$ & $\%$ & Constant & $\%$ \\
\hline $\mathrm{q} 10$ & -0.6802 & $-269 \%$ & -0.3424 & $-136 \%$ & -0.0191 & $-8 \%$ & -0.2878 & $-114 \%$ & 1.5820 & $627 \%$ \\
\hline q20 & 0.2484 & $-268 \%$ & 0.6430 & $-694 \%$ & $-0.4557^{*}$ & $492 \%$ & -0.0963 & $104 \%$ & -0.4321 & $466 \%$ \\
\hline q30 & $1.4843^{*}$ & $-615 \%$ & 0.5330 & $-221 \%$ & -0.1701 & $71 \%$ & $0.4745^{* *}$ & $-197 \%$ & $-2.5629^{*}$ & $1063 \%$ \\
\hline $\mathrm{q} 40$ & $1.4973^{*}$ & $-549 \%$ & 1.2103 & $-444 \%$ & 0.2979 & $-109 \%$ & -0.0157 & $6 \%$ & $-3.2625^{* *}$ & $1196 \%$ \\
\hline q50 & 1.2879 & $-692 \%$ & 0.1330 & $-71 \%$ & 0.1123 & $-60 \%$ & 0.0885 & $-48 \%$ & -1.8078 & $971 \%$ \\
\hline $\mathrm{q} 60$ & 1.2367 & $-590 \%$ & 0.0356 & $-17 \%$ & -0.1707 & $81 \%$ & 0.1851 & $-88 \%$ & -1.4964 & $714 \%$ \\
\hline $\mathrm{q} 70$ & 0.8032 & $7875 \%$ & 1.6744 & $16416 \%$ & $-0.4840^{*}$ & $-4745 \%$ & 0.0454 & $445 \%$ & -2.0288 & $-19890 \%$ \\
\hline q80 & 0.9156 & $-573 \%$ & $2.7150 *$ & $-1698 \%$ & $-0.7454^{*}$ & $466 \%$ & 0.0755 & $-47 \%$ & -3.1206 & $1952 \%$ \\
\hline q90 & 1.6451 & $2531 \%$ & $4.3679 *$ & $6720 \%$ & $-1.0491^{*}$ & $-1614 \%$ & $0.8628 *$ & $1327 \%$ & $-5.7617 *$ & $-8864 \%$ \\
\hline
\end{tabular}

Source: Elaborated by the authors based on the Continuous PNAD.

$* * * \mathrm{p}<0.01, * * \mathrm{p}<0.05, * \mathrm{p}<0.1$ 
Table A.2.6

Structural effect decomposition - Women

\begin{tabular}{c|c|c|c|c|c|c|c|c|c|c}
\hline Quantis & $\begin{array}{c}\text { Demographic } \\
\text { Characteristics } \\
\text { and human } \\
\text { capital }\end{array}$ & $\%$ & $\begin{array}{c}\text { Labor } \\
\text { market }\end{array}$ & $\%$ & $\begin{array}{c}\text { Groups of } \\
\text { activities } \\
\text { and } \\
\text { occupations }\end{array}$ & $\%$ & $\begin{array}{c}\text { Geography } \\
\text { and time }\end{array}$ & $\%$ & Constant & $\%$ \\
\hline q10 & -1.0385 & $-1229 \%$ & -0.0998 & $-118 \%$ & 0.1130 & $134 \%$ & $-0.6181 * * *$ & $-731 \%$ & $1.7279 *$ & $2045 \%$ \\
\hline q20 & -0.6583 & $1215 \%$ & 0.1769 & $-326 \%$ & -0.0429 & $79 \%$ & -0.1267 & $234 \%$ & 0.5968 & $-1101 \%$ \\
\hline q30 & 0.0614 & $389 \%$ & 0.1972 & $1248 \%$ & -0.0517 & $-327 \%$ & 0.1469 & $930 \%$ & -0.3380 & $-2139 \%$ \\
\hline q40 & $0.8929 *$ & $2706 \%$ & 0.0278 & $84 \%$ & 0.0866 & $262 \%$ & 0.1240 & $376 \%$ & -1.0983 & $-3328 \%$ \\
\hline q50 & 0.5106 & $693 \%$ & -0.3861 & $-524 \%$ & $0.3593 * *$ & $488 \%$ & 0.0518 & $70 \%$ & -0.4619 & $-627 \%$ \\
\hline q60 & 0.7311 & $3221 \%$ & 0.1206 & $531 \%$ & $0.4091 *$ & $1802 \%$ & 0.1908 & $841 \%$ & -1.4289 & $-6295 \%$ \\
\hline q70 & $2.5210 * *$ & $13339 \%$ & 0.4469 & $2365 \%$ & 0.4025 & $2130 \%$ & 0.4183 & $2213 \%$ & $-3.7698 * *$ & $-19946 \%$ \\
\hline q80 & 1.0257 & $541 \%$ & 0.9306 & $491 \%$ & $0.5256 *$ & $277 \%$ & 0.3182 & $168 \%$ & $-2.6106 * *$ & $-1378 \%$ \\
\hline q90 & 2.0285 & $743 \%$ & -0.1205 & $-44 \%$ & $0.8464 *$ & $310 \%$ & 0.2782 & $102 \%$ & -2.7595 & $-1010 \%$ \\
\hline
\end{tabular}

Source: Elaborated by the authors based on the Continuous PNAD.

*** $\mathrm{p}<0.01, * * \mathrm{p}<0.05, * \mathrm{p}<0.1$ 